\title{
The timing of deglaciation and sequence of pioneer vegetation at Ringsaker, eastern Norway - and an earthquake-triggered landslide
}

\author{
Jan Mangerud 1,2, Hilary H. Birks'2,3, Lene S. Halvorsen 3,7, Anna L. C. Hughes ${ }^{1,2}$, Ole \\ Nashoug ${ }^{4}$, Johan Petter Nystuen ${ }^{5}$, Aage Paus ${ }^{2,3}$, Rolf Sørensen ${ }^{6}$ \& John Inge Svendsen ${ }^{1,2}$ \\ ${ }^{1}$ Department of Earth Science, University of Bergen, P.O. Box 7803, NO-5020 Bergen, Norway. \\ ${ }^{2}$ Bjerknes Centre for Climate Research, Bergen, Norway. \\ ${ }^{3}$ Department of Biology, University of Bergen, P.O. Box 7803, NO-5020 Bergen, Norway. \\ ${ }^{4}$ Mammuthus, Hamar, Gåsbuvegen 890, NO-2323 Ingeberg, Norway. \\ ${ }^{5}$ Department of Geosciences, University of Oslo, P.O. Box 1047 Blindern, NO-0316 Oslo, Norway. \\ ${ }^{6}$ Faculty of Environmental Sciences and Natural Resource Management, Norwegian University of Life Sciences, P.O. Box 5003, NO-1432 Aas, Norway. \\ ${ }^{7}$ Department of Natural History, University Museum of Bergen, University of Bergen, P.O. Box 7800, NO-5020 Bergen, Norway.
}

E-mail corresponding author (Jan Mangerud): jan.mangerud@uib.no

We describe a sediment sequence comprising a thick till covered by thin beds of lacustrine sediments containing pollen and plant macrofossils derived from pioneer vegetation. Four consistent radiocarbon dates on terrestrial plant remains from the lacustrine sediments yielded an age of 10,500 calibrated years BP (cal years BP). This is the first accurate and precise age obtained for the deglaciation of the Mjøsa region in eastern Norway. We estimate that the ice-margin retreat rate in this area was about $250 \mathrm{~m}$ per year. Light-demanding herbs and Hippophaë rhamnoides were the first to colonise locally. When soils matured, birch immigrated to the area forming the first forests at around 10,200 cal years BP. This was rapidly followed by pine and aspen and, later, by black alder at c. $9000 \mathrm{cal}$ years BP. The lacustrine sediments are covered by $50 \mathrm{~cm}$ of peat and capped by a two-metre thick, coarse-grained, debris-flow deposit. The latter was surprising because of the very gentle slopes, four degrees in the failure area and less than three in the run-out and depositional area. We propose that the landslide, postdating the top of the peat that is dated to $6360 \mathrm{cal}$ years BP, was triggered by a strong earthquake.

Keywords: Scandinavian Ice Sheet, Fennoscandian Ice Sheet, Early Holocene, Preboreal, Holocene Earth Quake, Ice-margin retreat

Received 16. January 2018 / Accepted 25. May 2018 / Published online 1. September 2018

\section{Introduction}

The age of the deglaciation of the last Scandinavian Ice Sheet in the interior of Norway is poorly constrained (Hughes et al., 2016). For the entire area from the southern end of Lake Mjøsa (Fig. 1) to the location of the ice divide, a stretch of some $200 \mathrm{~km}$, only a single radiocarbon age related to the deglaciation is published, and this date, from Saug (Fig. 1), has a large uncertainty; 10,247-10,646 cal years BP (68.3\% confidence interval; Sørensen, 1982). Some details about the site at Saug are given below. In this paper we present a series of new dates that have been obtained from a recently exposed section on the farm Hemma, in the municipality of Ringsaker, between Hamar and Lillehammer (Figs. 1 \& 2). Three dates obtained from terrestrial plant macrofossils found in lacustrine sediments draping a till yielded very consistent ages, and we consider that they provide a precise and accurate age of the deglaciation of the area. The Early Holocene sequence of 50-70 $\mathrm{cm}$ of peat above the lacustrine layer, is buried by an enigmatic landslide deposit which must be attributed to an extreme event, probably a strong earthquake, as the slopes here have gradients of only $2.6-4^{\circ}$.

Mangerud, J., Birks, H.H., Halvorsen, L.S., Hughes, A.L.C., Nashoug, O., Nystuen, J.P., Paus, A., Sørensen, R. \& Svendsen, J.I. 2018: The timing of deglaciation and sequence of pioneer vegetation at Ringsaker, eastern Norway - and an earthquake-triggered landslide. Norwegian Journal of Geology 98, 315-332. https://dx.doi.org/10.17850/njg98-3-03. 


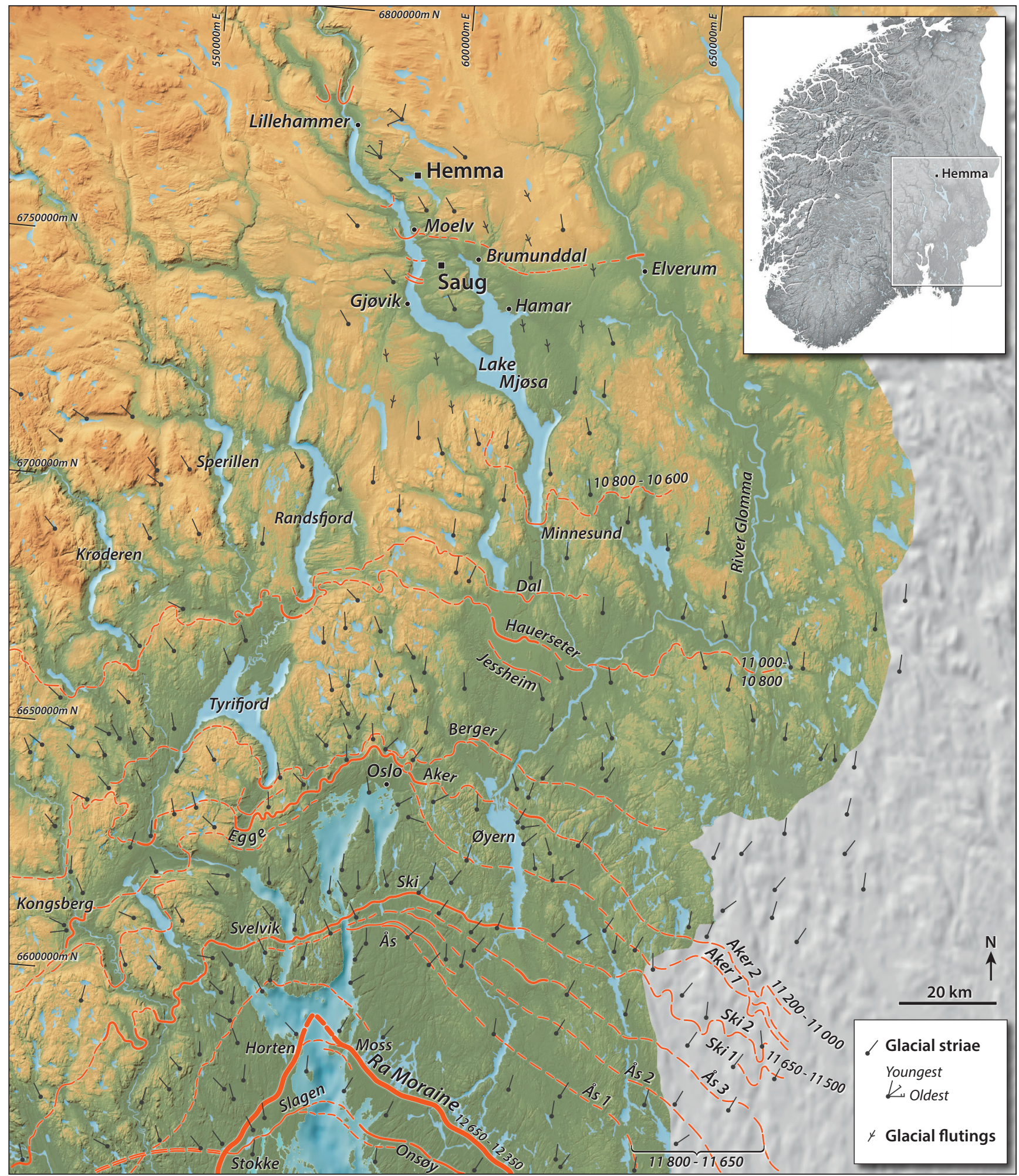

Figure 1. Map of end moraines and ice-front deposits (red lines) and glacial flow direction elements in southeastern Norway. For the area south of Minnesund the map is modified from Vorren \& Mangerud (2008). Flow elements north of Minnesund are from Follestad (2015). The age intervals given for moraines indicate uncertainties, not the duration of stillstands. The ages are given in calibrated years. The dark green areas are located below $300 \mathrm{~m}$ a.s.l., yellowish colours from 300 to 1000 and brown above $1000 \mathrm{~m}$ a.s.l. The small black square named Hemma in the upper part of the map indicates the location of Fig. 2. The inset map shows the location of the area in southern Norway.

In contrast, the Oslofjorden area to the south of Lake Mjøsa is a classical area for studies of the last deglaciation (Holtedahl, 1953, 1960; Sørensen, 1992). Here, a series of ice-front deposits are mapped, from the Ra Moraine dated to the Younger Dryas and crossing Oslofjorden between Moss and Horten, to Minnesund at the southern end of Lake Mjøsa (Fig. 1). The northernmost of these that is radiocarbon-dated is the Hauerseter 

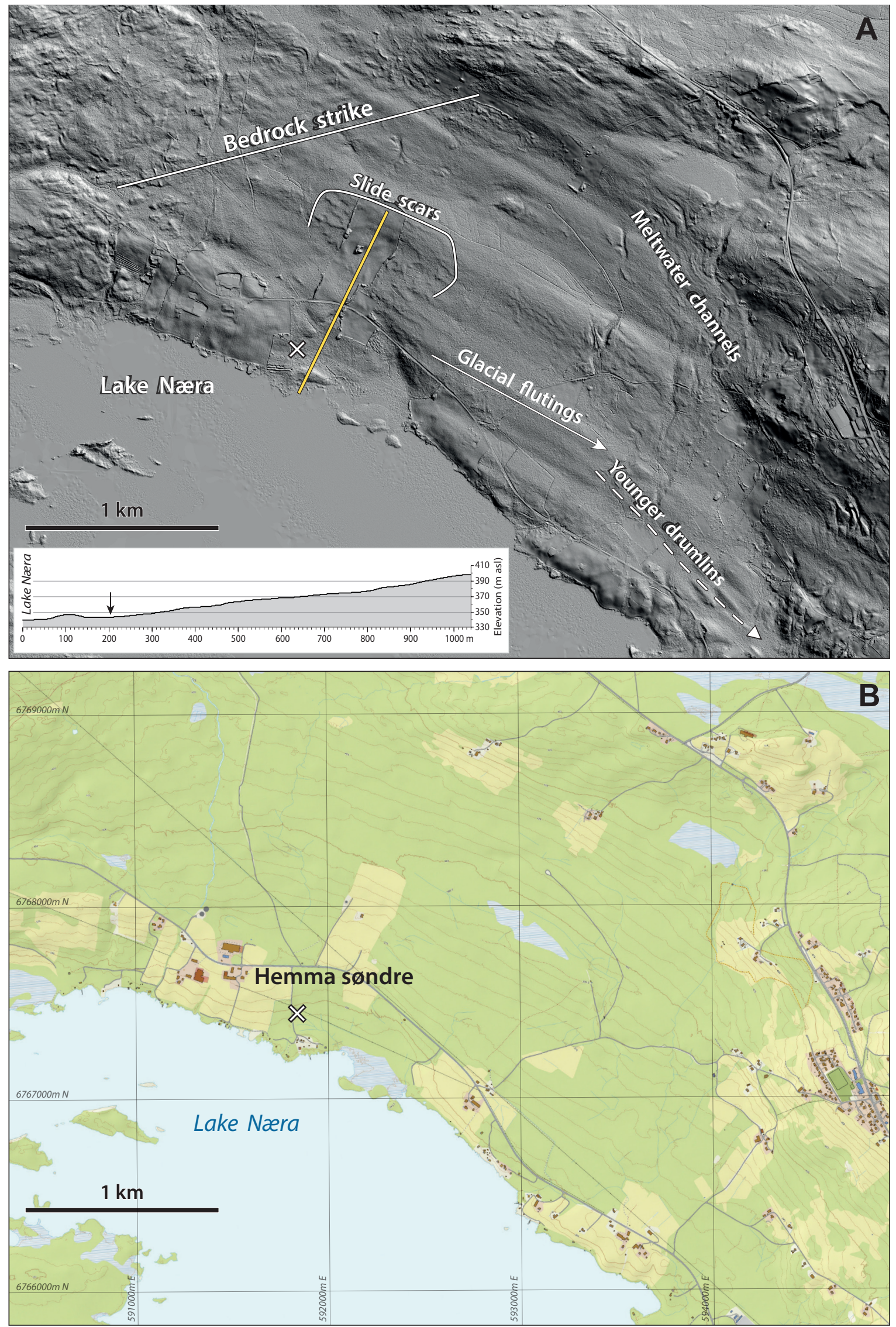

Figure 2. (A) Hill-shaded rendition of LiDAR-derived DTM with interpretations of landforms. The DTM is illuminated from NE and vertically exaggerated $4 x$. Some more slide scars can be seen on the same fluting, southeast of those marked. A long-profile through the slide is shown. The arrow indicates a direction of ice flow shown by glacial lineations. The lineations form part of a regionally extensive ice-flow pattern (Fig. 3). The dashed arrow shows ice flow depicted by younger drumlins. (B) Map of the same area. X marks the location of the described section in both figures. (http://www.norgeskart.no/\#!?project=seeiendom\&layers=1002,1015\&zoom=4\&lat=7197864.00\&lon=396722.00). 
sandur (Sørensen, 1982; Longva \& Thoresen, 1989), where the average of two dates is $11,015 \pm 670$ cal years BP. The northernmost well-defined ice-front deposit is the Minnesund glaci-fluvial delta, which has a $70 \mathrm{~m}$-high ice-contact slope rising from the shore of Lake Mjøsa (123 $\mathrm{m}$ a.s.l.) and up to the delta surface. The Minnesund delta has been assigned an age of 10,700-10,800 cal years BP based on plotting the altitude of the marine limit in a dated shore-line diagram (Sørensen, 1992). Overall, icemargin retreat in the Oslofjorden area is reasonably well dated, although some uncertainties remain (Fig. 1).

The Quaternary map of the Mjøsa region shows that the terrain is mainly covered by till north of Minnesund (Follestad, 2015). On both sides of Lake Mjøsa, stagnant ice features such as hummocky moraines, kettle-holes, and downhill eskers oriented at right angles to ice-flow directions indicated by drumlins, and striations are common, suggesting that the ice sheet in this area mainly down-wasted vertically (Follestad, 2017). However, we consider that the ice sheet nevertheless had a defined icemargin as it retreated northwards from Minnesund based on the following evidence. Near and south of Moelv (Fig. 1), seismic profiles in Lake Mjøsa show three distinct till ridges that are interpreted as ice-marginal deposits of an active glacier (Aagaard, 1976). We correlate the ridge across Mjøsa at Moelv with glaci-fluvial deposits at Brumunddal, and with a large ice-marginal delta at Elverum (Sørensen, 1983), although we cannot trace the former ice margin between Brumunddal and Elverum (Fig. 1). The delta at Elverum was probably formed during the catastrophic drainage of an ice-dammed lake that seems to have happened between 10,200 and 10,500 cal years BP (Longva, 1994; Høgaas \& Longva, 2016). This age is supported by optically stimulated luminescence (OSL) dates that give ages of 10,600-9800 BP from aeolian dunes that formed shortly after the drainage event (Alexanderson \& Henriksen, 2015).

The only published pollen diagram from the Mjøsa district that includes the first vegetation that established soon after the deglaciation is from Lake Valetjern (Hafsten, 1956, 1975), about $45 \mathrm{~km}$ SSE of Hemma and just south of Hamar (Fig. 1). Here, pioneer herbs and Hippophaё rhamnoides established first, followed by light-demanding forests of birch and aspen. Pine trees were sparsely present, but expanded later together with hazel and alder. However, no ${ }^{14} \mathrm{C}$-dates are available from Våletjern. In this paper, we present pollen diagrams from both Hemma and Saug; the latter is an old, previously unpublished and less detailed diagram. We also present plant macrofossil data representing the pioneer vegetation at Hemma.

\section{Methods}

High-resolution (1 m) LiDAR (Light Detection and Ranging) elevation data were obtained for the study area from Kartverket (Norwegian National Mapping authority, hoydedata.no) in multiple formats (pointcloud, digital surface and digital terrain models). The region is densely forested and so the bare-earth digital terrain model (DTM), where vegetation and cultural features have been filtered out, was chosen for further processing. The DTM was processed using ArcMap 10.4 software to generate multiple hill-shaded images of the terrain. To avoid azimuth bias we generated hill-shaded images with the sun positioned at $45^{\circ}$ (NE) and $315^{\circ}(\mathrm{NW})$, and to highlight subtle features within the landscape used a solar elevation of $40^{\circ}$ and a vertical-exaggeration of $4 \mathrm{x}$ (Hughes et al., 2010). These renditions of the DTM were used to map out and delineate the dimensions of the landslide and the glacial features of the area (Fig 2). The DTM was also used to generate slope profiles across the landslide scar.

Loss-on-ignition (LOI) of organic sediments calculated as $\%$ loss of dry weight was measured by drying samples at $105^{\circ} \mathrm{C}$ and igniting at $550^{\circ} \mathrm{C}$.

All radiocarbon ages from Hemma were obtained from wood or terrestrial plant fragments using accelerator mass spectroscopy (AMS; Table 1); details of some of the samples are given below. Two samples from Saug were dated with conventional methods. The lowest consists of moss remains, the upper of wood (possibly Alnus). Ages were calibrated using Calib 7.1 (Stuiver et al., 2017) and the IntCal13 calibration curve (Reimer et al., 2013). All radiocarbon ages in the text are reported as calibrated years BP before 1950 (cal years BP).

Pollen samples $\left(1 \mathrm{~cm}^{3}\right)$ were extracted from the Hemma core 46, with at least one sample from each sediment layer. From the Saug site eight pollen samples were collected from the wall of a ditch dug in the centre of a bog. All samples were treated with HF and acetolysed following Fægri et al. (1989). In the pollen diagrams, the percentage calculation basis $(\Sigma \mathrm{P})$ comprises the terrestrial pollen taxa. For a taxon $\mathrm{X}$ of aquatic plants $(\mathrm{AQP})$ and spores, the calculation basis is $\Sigma \mathrm{P}+\mathrm{X}$. The pollen diagrams were divided into local pollen assemblage zones (paz) by visual inspection. The pollen diagrams were drawn using the program CORE 2.0 (Natvig \& Kaland, 1994).

Macrofossil samples were taken from the basal part of the same core, from the silt, the sand, the upper silt, and the gyttja beds. Volumes of the analysed samples were measured by displacement of water and the results standardised to numbers of remains in $50 \mathrm{~cm}^{3}$. Samples were dispersed in water and washed through a $125 \mu \mathrm{m}$ sieve. Remains were systematically picked out of the 
Table 1. Radiocarbon samples from Hemma and Saug.

\begin{tabular}{|c|c|c|c|c|c|c|c|c|}
\hline \multirow{2}{*}{$\begin{array}{l}\text { "Sample } \\
\text { ID" }\end{array}$} & \multirow{2}{*}{$\begin{array}{l}\text { Radiocarbon } \\
\quad \text { lab. ID }\end{array}$} & \multirow[t]{2}{*}{${ }^{14} \mathrm{C}$ age } & \multirow[t]{2}{*}{$1 \sigma$} & \multicolumn{3}{|c|}{ Calibrated ages } & \multirow[t]{2}{*}{ Material dated } & \multirow[t]{2}{*}{ Stratigraphical position and comments } \\
\hline & & & & Median & $\begin{array}{r}68 \\
\text { confider }\end{array}$ & $\begin{array}{l}\% \\
\text { e limits }\end{array}$ & & \\
\hline Hemma 2C & Beta- 480132 & 5590 & 30 & 6361 & 6319 & 6403 & $\begin{array}{l}\text { Hand-picked terrestrial } \\
\text { bark }\end{array}$ & Core 46 . The very top of the peat. \\
\hline Hemma-31 & Beta- 454223 & 8620 & 30 & 9559 & 9536 & 9594 & Piece of wood & $\begin{array}{l}\text { Collected in the middle of the peat in section } 2 \text {. } \\
\text { This is close to core } 46 .\end{array}$ \\
\hline Hemma-46-2 & Beta- 456320 & 9740 & 40 & 11188 & 11165 & 11220 & $\begin{array}{l}\text { Plant material, washed } \\
\text { and sieved at } 250 \mu \mathrm{m}\end{array}$ & $\begin{array}{l}\text { Core } 46 \text {. Base of organic sequence, } 9-10 \mathrm{~cm} \text { above } \\
\text { bottom of core. We conclude that the age is too old } \\
\text { due to reservoir age of the lake water. }\end{array}$ \\
\hline Hemma-46-3 & Beta- 456321 & 8640 & 30 & 9583 & 9541 & 9605 & $\begin{array}{l}\text { Plant material, washed } \\
\text { and sieved at } 250 \mu \mathrm{m}\end{array}$ & "Core 46, 44-46 cm above bottom." \\
\hline Hemma-46-4 & Poz-93349 & 9250 & 50 & 10422 & 10299 & 10509 & $\begin{array}{l}\text { Hand-picked terrestrial } \\
\text { plant macrofossils }\end{array}$ & $\begin{array}{l}\text { Core } 46 \text {. The lowermost silt, } 2-4.5 \mathrm{~cm} \text { above bottom } \\
\text { of core (Fig. } 5 \text { ). Parellel with pollen sample } 1 \text { and } \\
\text { macro sample } 1 .\end{array}$ \\
\hline Hemma-46-5 & Poz-93350 & 9240 & 60 & 10409 & 10297 & 10500 & $\begin{array}{l}\text { Hand-picked terrestrial } \\
\text { plant macrofossils }\end{array}$ & $\begin{array}{l}\text { Core } 46 . \text { Bed of very fine sand, } 4.5-7 \mathrm{~cm} \text { above } \\
\text { bottom of core. Parellel with pollen sample } 2 \text { and } \\
\text { macro sample } 2 \text {. }\end{array}$ \\
\hline Hemma-46-6 & Poz-93351 & 9270 & 60 & 10448 & 10302 & 10560 & $\begin{array}{l}\text { Hand-picked terrestrial } \\
\text { plant macrofossils }\end{array}$ & $\begin{array}{l}\text { Core } 46 . \text { The upper silt, } 7-9 \mathrm{~cm} \text { above bottom of core. } \\
\text { Parellel with pollen sample } 3 \text { and macro sample } 3 \text {. }\end{array}$ \\
\hline Hemma-46-7 & Poz-93352 & 9060 & 50 & 10224 & 10197 & 10245 & $\begin{array}{l}\text { Hand-picked terrestrial } \\
\text { plant macrofossils }\end{array}$ & $\begin{array}{l}\text { Core } 46 . \text { Massive fine-grained gyttja. Base of organic } \\
\text { sequence, } 9-10 \mathrm{~cm} \text { above bottom of core. } \\
\text { Parallel sample to Hemma- } 46-2 \text { (Beta- } 456320) \text {. } \\
\text { Parellel with pollen sample } 4 \text { and macro sample } 4 \text {. }\end{array}$ \\
\hline Saug-1 & $\mathrm{T}-1531$ & 9260 & 150 & 10465 & 10247 & 10646 & Mosses & $\begin{array}{l}\text { Thin layers of mosses in silty gyttja at the base of the } \\
\text { bog, depth } 102 \mathrm{~cm} .\end{array}$ \\
\hline Saug-2 & T-1746 & 8930 & 140 & 10002 & 9794 & 10229 & $\begin{array}{l}\text { Piece of wood, } \\
\text { possibly Alnus }\end{array}$ & Depth in bog $65 \mathrm{~cm}$. \\
\hline
\end{tabular}

residue, identified and counted. The macrofossil diagram was constructed in TILIA (Grimm, 1990) and drawn in TGView (Grimm, 2004).

\section{Sites and fieldwork}

In this paper, we focus on the stratigraphic results from the site Hemma (Figs. 2 \& 3), where we conducted fieldwork in December 2016. As the Saug locality (Fig. 1), studied by Rolf Sørensen in the 1970s, has not been described in the scientific literature before, we also include a short description and present results from that site.

\section{The Hemma site $\left(60.0312^{\circ} \mathrm{N}, 10.699^{\circ} \mathrm{E}\right)$}

The farmer Jan Tore Hemma discovered the site when cultivating an area tightly packed with large boulders, which in some places formed a surface layer (Figs. 4 \& 5). He dug 2-3 m-deep ditches in which he deposited the boulders in order to remove them and improve drainage of the field. At one site, he discovered a peat bed underneath both the boulder layer and a diamicton (Fig. 4). He was surprised to find peat containing large tree trunks below such deposits and contacted us. We visited the site in December 2016, when the ground was frozen. After looking at the exposed strata in the ditches and considering the surrounding terrain, we proposed two alternative hypotheses; first, that the peat is of Holocene age and overlying strata are landslide deposits, and second, that the peat is of interglacial age and the overlying strata are glacial deposits. We did not consider it likely that a major landslide had taken place on this gentle slope $\left(2.6^{\circ}\right)$, in spite of certain indicative features in the stratigraphy. In the field, we therefore favoured the second hypothesis that glacial ice had overrun the peat, and that the diamicton was a basal till and the boulder bed a surface melt-out till. Due to the frozen ground and the short time available for further field studies during our visit, we decided that a radiocarbon date would be the easiest way to falsify one of the hypotheses. To our surprise, the radiocarbon sample gave an Early Holocene age, supporting the first hypothesis that the diamicton and boulder bed covering the peat are indeed landslide deposits. 


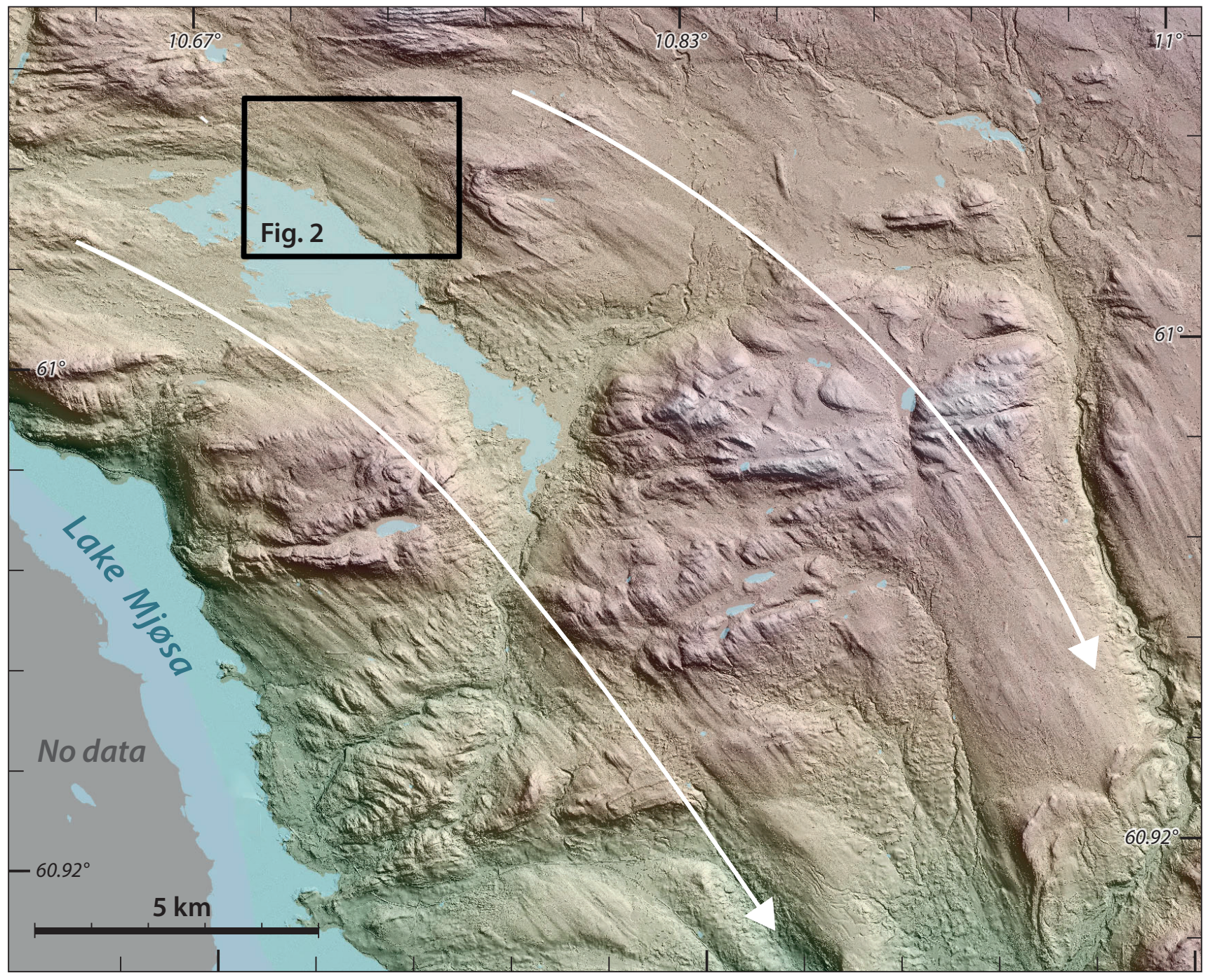

Figure 3. Hill-shaded rendition of LiDAR-derived DTM of a somewhat larger area to show the regional context. The direction of the large lineations at Hemma form part of a regionally extensive ice-flow pattern depicted by lineations, drumlins, and crag and tails. Long arrows show the ice-flow direction bending from a southeasterly to a more southerly direction across the area. The rectangle indicates Fig. 2 . The DTM is illuminated from NE and vertically exaggerated $4 \mathrm{x}$. Colours give indication of elevation.

The site is located on a gentle slope with an angle of about $2.6^{\circ}$, only some eight metres above Lake Næra, which currently has a lake level at $340 \mathrm{~m}$ a.s.l., (Fig. 2). We have studied images derived from high-resolution LiDAR data but not conducted field studies of the surrounding area. The hill-shaded rendition of the LiDAR-derived DTM shows large glacial lineations orientated WNW-ESE (Fig. 2) and which form part of a regionally extensive ice flow (Fig. 3). Some smaller NW-SE orientated drumlins are superimposed on the larger lineations. These indicate a change in ice-flow direction towards Lake Mjøsa, which probably occurred late during the deglaciation, when the ice margin calved back in the lake Mjøsa basin. Meltwater channels cut across the lineations and run steeply downhill (Fig. 2). We interpret these as being formed subglacially, and since they have not been destroyed, probably under a slow-moving glacier.

\section{The Saug site $\left(60.8667^{\circ} \mathrm{N}, 10.822^{\circ} \mathrm{E}\right)$}

The Saug site (Fig. 1) is a small bog at $249 \mathrm{~m}$ a.s.l. filling a dead-ice depression in the western part of a hummocky till area (Rye, 1979), presently on the edge of cultivated land. A pit was dug in the middle of the bog. The bog is $102 \mathrm{~cm}$ deep with silt at the base, overlain by $15 \mathrm{~cm}$ of coarse silty gyttja. The rest of the section is a highly decomposed peat, with a trunk of wood at $65 \mathrm{~cm}$ depth. At $50 \mathrm{~cm}$ depth several root-stumps were observed. The upper $25-30 \mathrm{~cm}$ are disturbed by ploughing. A simple pollen diagram was produced for the lower half of the section, mainly as a support for the Quaternary mapping of the area and for radiocarbon dating of the deglaciation. 


\section{Results and discussion}

\section{Lithostratigraphy at Hemma}

At the base of the studied section, there is a (lower) diamicton that we interpret as a regional till unit, probably formed during, or soon after, the Last Glacial Maximum. The farmer dug an additional hole down to almost $6 \mathrm{~m}$, to the left and shortly outside the site of the photo in Fig. 4, which revealed this diamicton all the way to the bottom, without reaching bedrock. We assume the major glacial flutings clearly visible in the hill-shaded renditions of the LiDAR DTM (Fig. 2) were formed in this till. The overlying units are shown in Figs. $4 \& 5$. The lower diamicton is succeeded by thin silt and sand beds that we collectively label the silt-sand member and interpret as lacustrine sediments. This member varies somewhat in thickness, about $10-30 \mathrm{~cm}$, between the exposures. The overlying peat, that also varies in thickness, is up to one metre thick and wedges out towards the southwest.

The top of the peat has an uneven boundary to a 50-100 $\mathrm{cm}$ thick (upper) diamicton. We observed small peat lenses in the lower part of this diamicton. The section is capped by a boulder layer that is up to one metre thick, but the thickness varies much around the sections.
Jointly, these two units are interpreted as landslide (debris flow) deposits, and described in more detail below. We observed thrust and/or sliding surfaces in several places within the succession. These were most common in the upper part of the peat, but in the section to the right in Fig. 4 there were also distinct sliding surfaces in the lowermost part of the peat. Below we describe core 46 that is most relevant for the present paper.

\section{Lithostratigraphy of core 46}

In order to secure a continuous sequence, we made a horizontal platform just above the peat, close to an exposure (No. 2) where we described the stratigraphy. From the surface of this platform we hammered down an $11 \mathrm{~cm}$ diameter PVC tube through the peat. The tube, labelled core 46, penetrated the peat and silt-sand member and stopped on top of the lower diamicton (till), possibly on a boulder. We give measurements from the base of the core and upwards in the succession, i.e., altitudes above the top of the lower diamicton (Fig. $6)$. The core contains the well-defined lower silt-sand member $(0-10 \mathrm{~cm}$, measured in the middle of the core) and the peat member from $10 \mathrm{~cm}$ to the top of the core $(63 \mathrm{~cm})$. These members are seen in most of the sections examined.

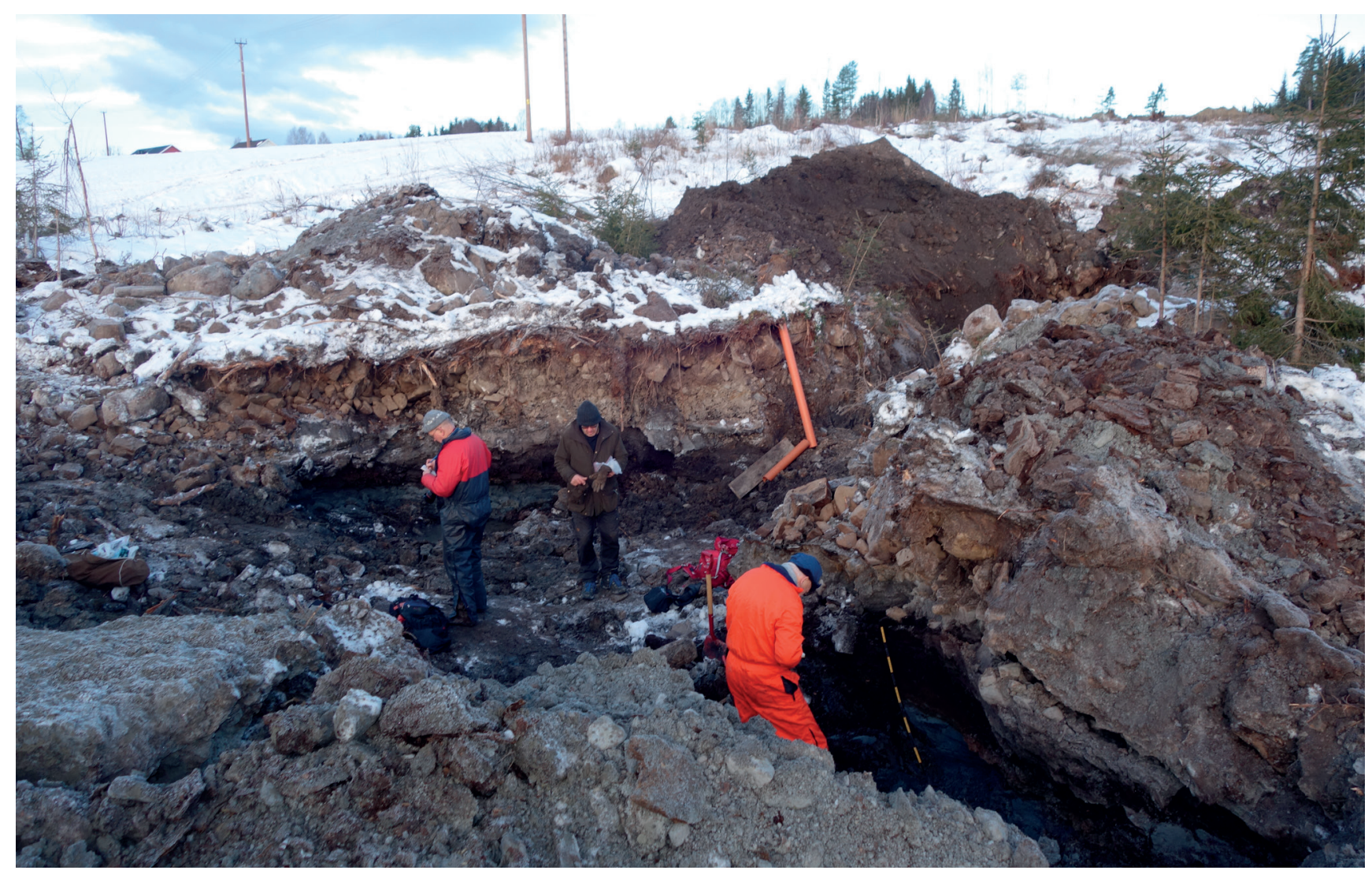

Figure 4. Photo of the site. The roofs of the farm Hemma Søndre (Fig. 2) can be seen in the background to the left. The photo in Fig. 5 shows the wall behind the man to the left. Core 46, used for radiocarbon dating, pollen, etc., was collected close to the tubes in the right part of the ditch. 


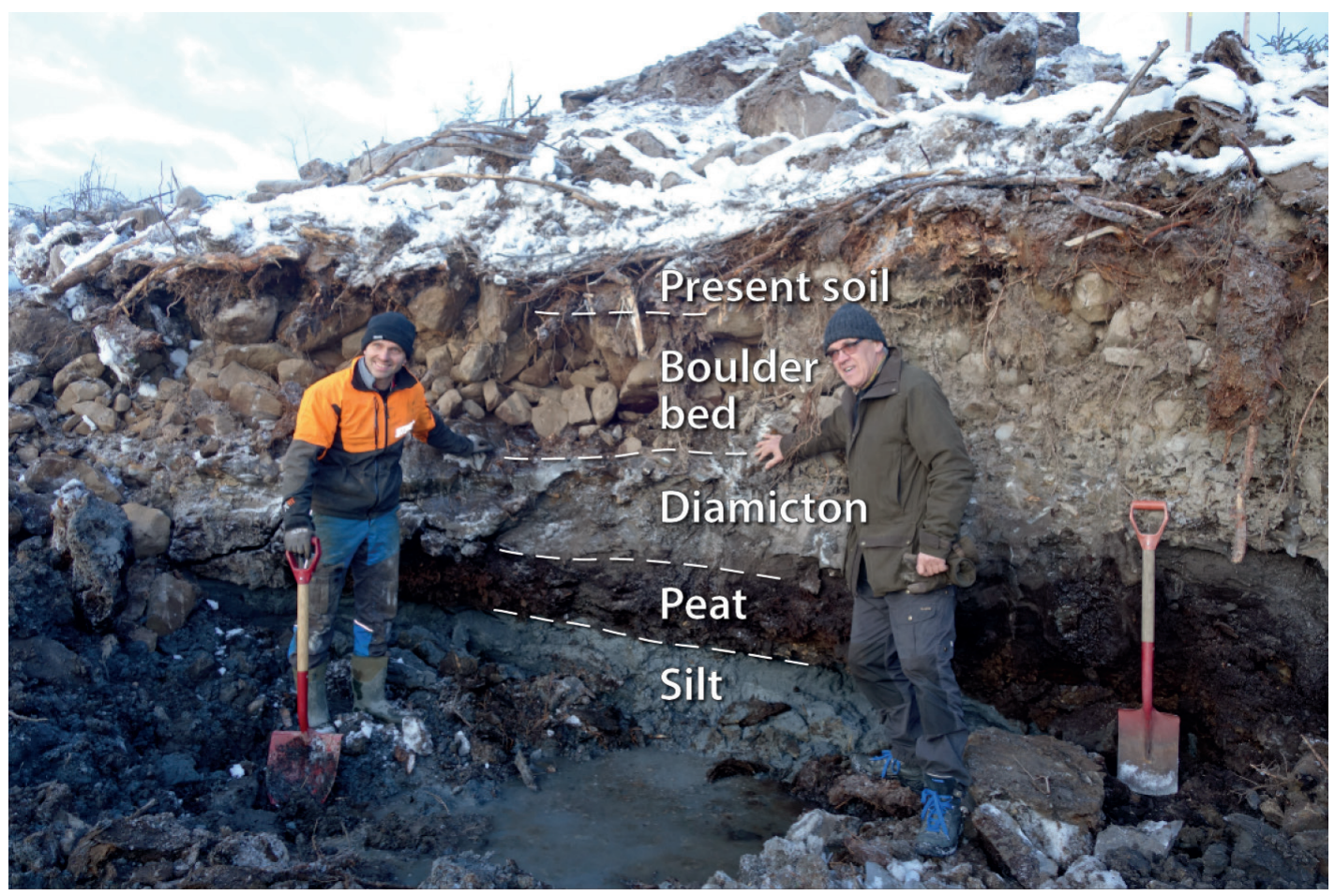

Figure 5. The stratigraphy in the ditch. The wall, and the heap on top, can be recognised in Fig. 4. Notice imbrication in the boulder bed, large boulders in top of the boulder bed and podzol profile (brown colour) in the modern soil.
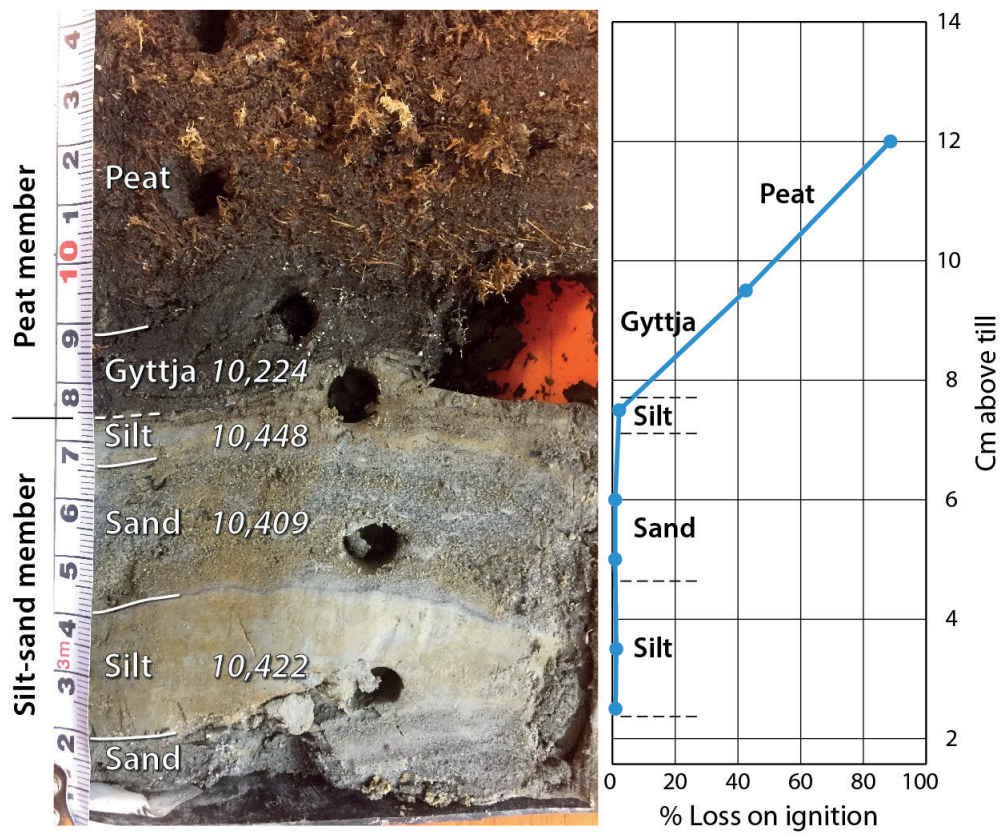

Figure 6. Photo of the lower part of Core 46, Hemma. The lithostratigraphical units are marked on the left side. The small circular holes are from pollen samples. The large hole to the right in the gyttja is from radiocarbon sample Hemma-46-2. The median age of the radiocarbon samples Hemma-46-4 to 46-7 are given as calibrated ages BP. Loss-on-ignition is shown along the core.

The lowest bed in the silt-sand member, $0-2 \mathrm{~cm}$ above the till, is a fine sand with silt laminae (Fig. 6). The bed was apparently somewhat disturbed during collection of the core and for this reason we did not subsample this bed. The sand is overlain by a silt bed $(2-4.5 \mathrm{~cm})$, where only faint laminae can be seen; the lowermost pollen and macrofossil samples are both from this bed.
Above follows a distinct bed $(4.5-7 \mathrm{~cm})$ of very fine sand with a band of 1-4 mm-thick silt lenses that probably represent a broken silt lamina. Pollen and macrofossil samples number 2 are from this bed. The uppermost bed in the member is an up to $1.5 \mathrm{~cm}$-thick silt layer $(7-8.5$ $\mathrm{cm}$ ) that is thicker in the middle of the core. There are thin discontinuous surfaces in the upper part, which we 
consider may be sliding surfaces. Pollen and macrofossil sample number 3 are from this bed. We interpret the silt-sand member to be lacustrine sediments deposited during deglaciation. These could have been formed in Lake Næra at a time when the lake level was least $8 \mathrm{~m}$ above present (340 $\mathrm{m}$ a.s.l.), for example if the present narrow outlet of the lake was blocked by sediments. Alternatively, the silt-sand member could have been deposited in a proximal lake to the down-melting ice sheet, or a local pond if the topography was different from the present.

The peat member starts with a bed of dark and dense lacustrine gyttja (8.5-10 cm above the till; Fig. 5). The radiocarbon ages suggest that there is a hiatus between the underlying silt and this gyttja. Considering the surfaces in the silt, described above, we assume that this hiatus reflects a removal of sediments during the slide event. There is a sharp boundary to the overlying light-brownish peat $(10-21 \mathrm{~cm})$ with visible mosses and other plant remains, including a piece of wood. In the lower part, the peat is hardly humified, but humification varies upwards; between 21 and $28 \mathrm{~cm}$ the peat is more humified, at $28-40 \mathrm{~cm}$ lighter and less humified, from 40 to $50 \mathrm{~cm}$ again more humified, and from about 50 $\mathrm{cm}$ silt and coarse sand occur in the peat. The upper part is probably disturbed by the landslide. Tree logs, branches and other wood remnants are seen in several places nearby in the ditches, Some were collected and the species were identified (Table 2).

\section{Radiocarbon ages}

The first submitted sample, Hemma-46-2, was washed through a $250 \mu \mathrm{m}$ sieve and consisted of only plant remains, including mosses. It yielded an age of $11,188 \mathrm{cal}$ years BP (Table 1) (Mangerud et al., 2017). This age was much older than we expected based on the presumed regional age of deglaciation. We now consider it likely that the unexpectedly old age is due to a reservoir effect in the lake because we found numerous fossil remains of Chara among the plant macrofossils, a taxon that prefers carbonate-rich water. Therefore we submitted a series of samples that were taken in stratigraphic order.

After discovering the hard-water effect, we carefully hand-picked terrestrial plant macrofossils from samples 46-4 to -7. These samples were taken from each of the beds in the silt-sand member and the gyttja layer, respectively (Fig. 6). The three samples (46-5 to 46-7) from the silt-sand member and gyttja yielded almost identical radiocarbon ages (Table 1), suggesting that the sedimentation rate was rapid, as supported from the sediments. When modelling the four lower samples using the OxCal programme (Version 4.3; Bronk Ramsey, 2008,2009 ) we obtained an age for the boundary to the underlying till of 10,412-10,569 (68.4\% significance level), which with an approximation can be written as $10,490 \pm 80 \mathrm{cal}$ years BP (Fig. 7). Unfortunately, the three lowest radiocarbon samples are all located on a plateau in the calibration curve (Fig. 8). This explains why three such precise measurements, each with $1 \sigma<$ $60{ }^{14} \mathrm{C}$-years, do not provide more precise calibrated ages, and especially a more precise modelled age based on three samples.

Plant material from the middle part of the peat in core 46 gave an age of about $9600 \mathrm{cal}$ years BP, very similar to the age of a piece of wood from a similar stratigraphic position in section 2, and a sample of bark from the top of the peat that yielded 6319-6403 cal years BP (Table 1). The basal sample from Saug yielded a calibrated radiocarbon age of $10,247-10,646$ (68.4\% significance

Table 2. Wood analysis. All samples were collected during the fieldwork December 2016 except those marked *, which were collected by Nashoug at different occasions. $\wedge$ - Part of log that was dated to 9560 cal years BP (Beta-454223).

\begin{tabular}{|c|c|c|c|}
\hline $\begin{array}{l}\text { Sample } \\
\text { number }\end{array}$ & Location and stratigraphic position & Sample feature & Result \\
\hline 30 & Section 2, bottom of section. & Twig & Salix \\
\hline $31^{\wedge}$ & Section $2,45-50 \mathrm{~cm}$. & $\log$ & Pinus \\
\hline 34 & Across from section 2 , from «log layer». & Large log & Pinus \\
\hline 35 & Close to section 2. Possibly the same location as 31 or 34 . & Large log & Pinus \\
\hline 36 & Across from section 2, just above light peat (possibly the same as 34). & $\log$ & Pinus \\
\hline 38 & Section $2,60-65 \mathrm{~cm}$. & Twig & Pinus \\
\hline 43 & Across from section 2 . & $\begin{array}{l}\text { Large, well preserved twig. } \\
\text { Broken off trunk }\end{array}$ & Pinus \\
\hline 48 & Unknown. & $\log *$ & Salix \\
\hline 53 & Unknown, from peat. & $\begin{array}{l}\text { Twigs * } \\
\text { - three were analysed }\end{array}$ & $\begin{array}{l}\text { 1) Deciduous, } \\
\text { possible root } \\
\text { 2) Pinus } \\
\text { 3) Deciduous, } \\
\text { possible root }\end{array}$ \\
\hline
\end{tabular}




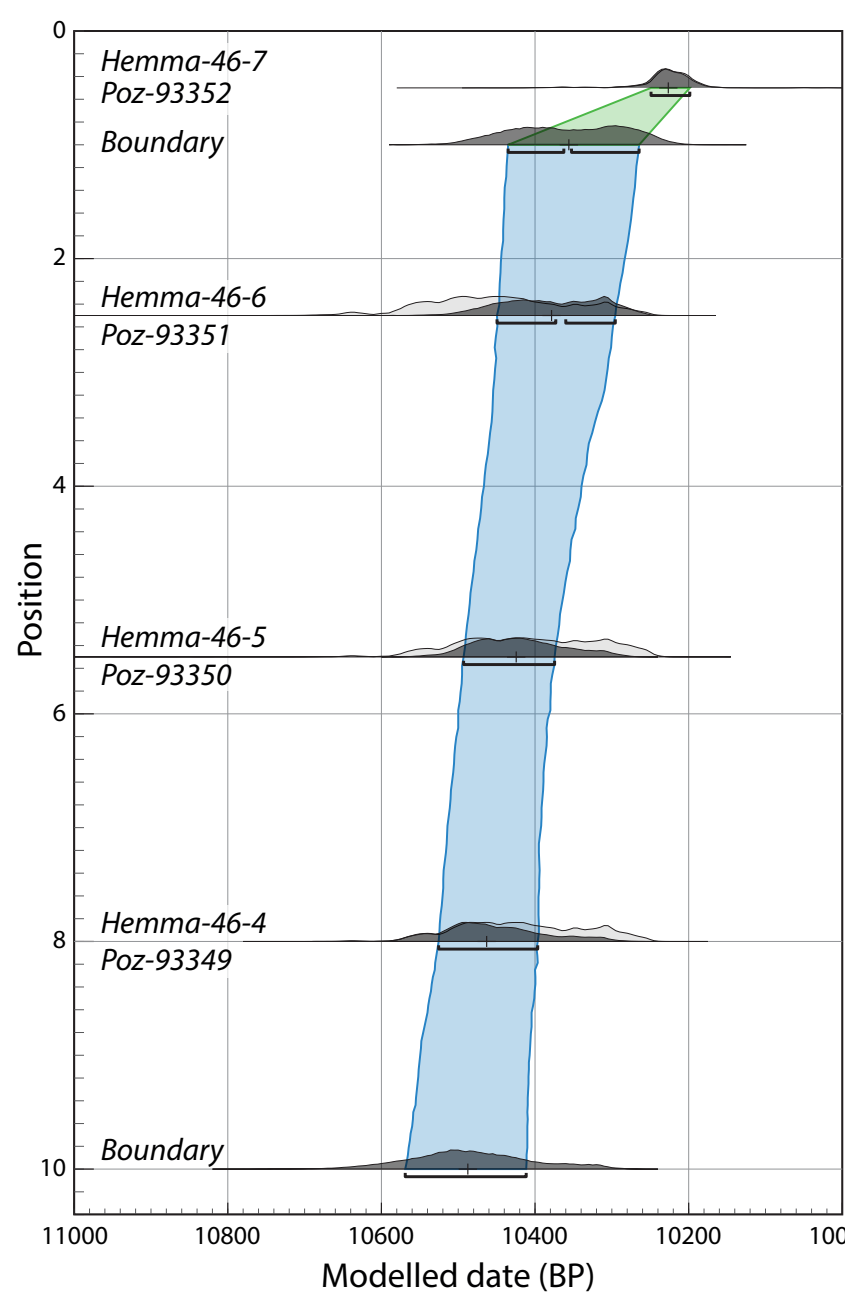

Figure 7. Age-depth model for the four lowest radiocarbon samples constructed using OxCal v. 3.1. (Bronk Ramsey, 2017) and the IntCal13 curve (Reimer et al., 2013). The modelled age for the boundary to the till is 10,412-10,569 and 10,311-10,629 years BP at 68.4 and $95.4 \%$ significance levels, respectively.

level), which with an approximation can be written as $10,446 \pm 200 \mathrm{cal}$ years BP (although the errors do not have a Gaussian distribution). The upper sample yielded a median age of 10,000 cal years BP, but with a large uncertainty.

\section{Vegetation development - pollen and plant macrofossil stratigraphy}

\section{The Hemma site}

The pollen data are divided into four pollen assemblage zones (paz; Fig. 9; Table 3). Paz H1 corresponds to the silt-sand member and overlying gyttja with one pollen sample from each bed (Fig. 6). Macrofossil analyses were made on four samples within H1 (Fig. 10), corresponding to the lithostratigraphy shown in Fig. 6. The pollen assemblage in zone $\mathrm{H} 1$ represents pioneer vegetation on the newly exposed mineral soils in the Early Holocene. Similar assemblages are recorded from newly deglaciated

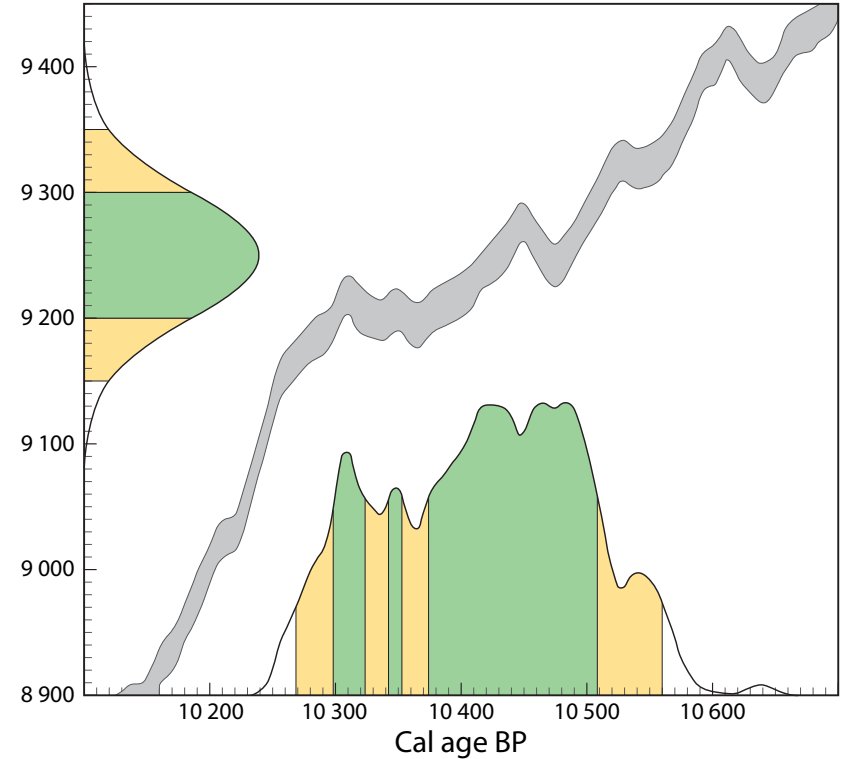

Figure 8. The calibration of sample Hemma-46-4, the lowermost radiocarbon sample, shows how narrow errors in the ${ }^{14} \mathrm{C}$ determination translate to large errors in calibrated ages (Stuiver et al., 2017). The grey curve is the IntCal13 curve (Reimer et al., 2013). The probability curve for the radiocarbon age is coloured green for one standard deviation and yellow for two. The calibrated ages are coloured correspondingly, green for $68.3 \%$ and yellow for the $95.4 \%$ significance levels for the given ages, respectively.

areas in southern Norway in the Late-Glacial (e.g., Høeg, 1982; Paus, 1989) and Early Holocene (Birks \& Peglar, 2012).

The pollen and macrofossil data will be interpreted together for zone H1. The leaves of Hippophaë rhamnoides and their characteristic stellate hairs in the basal sand and silt $(2-4 \mathrm{~cm} ; 10,420 \mathrm{cal}$ years BP) indicate its local presence. Other terrestrial plants include steppeplants (e.g., Artemisia, Chenopodiaceae) and arcticalpine plants (e.g., Betula nana, Botrychium). Plants of mossy fens and flushes are present (Parnassia palustris, Juncus, Epilobium palustre, and the northern Primula stricta). Chara and Potamogeton grew in the shallow water and provided habitats for aquatic invertebrates (Fig. 10). This suggests that the coring site was near the shore of a shallow lake bordered by base-rich flush or fen vegetation and some Hippophaë and Betula nana shrubs. The water was slightly calcareous, as shown by the presence of Chara, Potamogeton sect. Coleogeton and ostracods. 


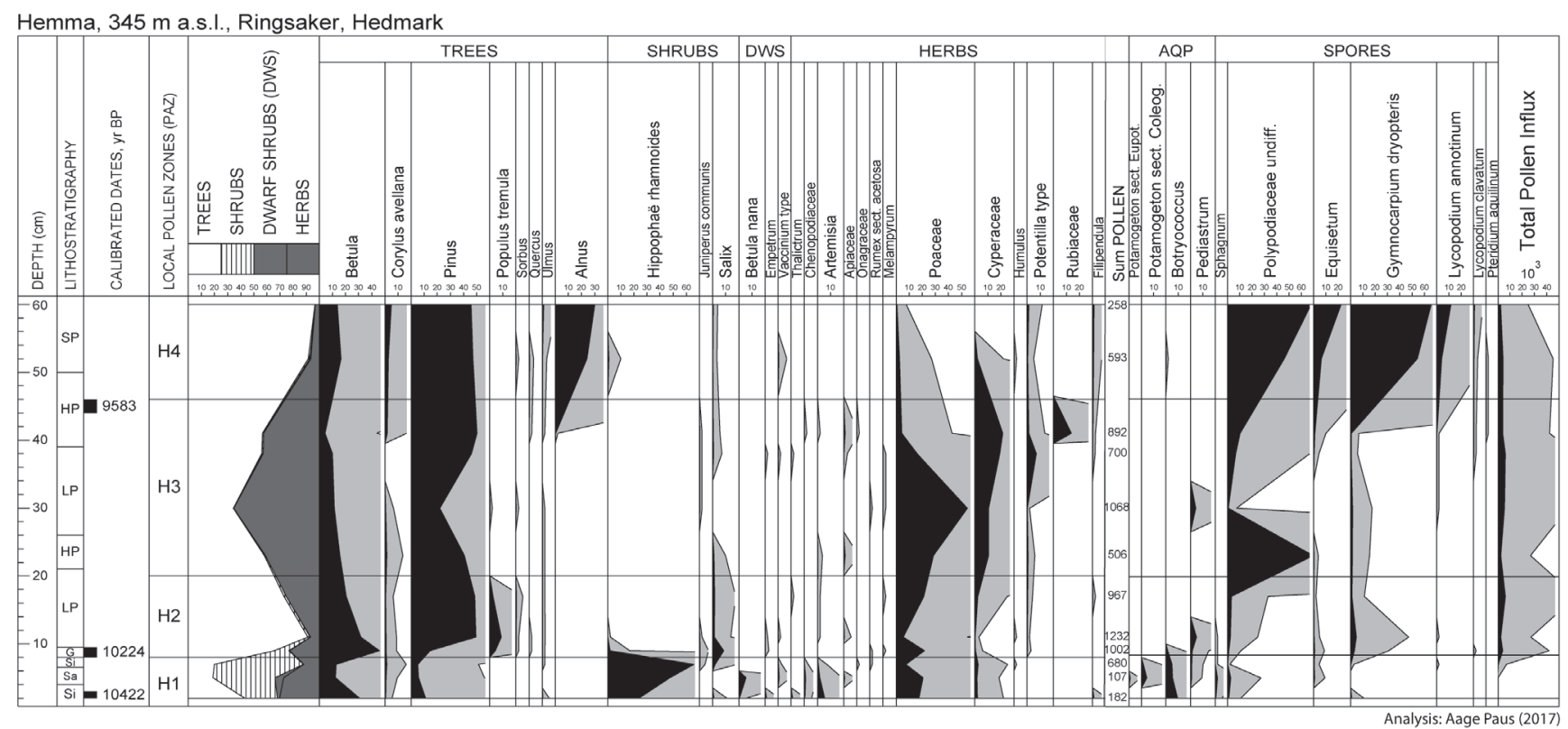

Figure 9. Percentage pollen diagram from Hemma. Shaded curves represent 10x exaggeration of the scale. Total pollen influx (pollen grains $\left.\mathrm{cm}^{-2} \mathrm{a}^{-1}\right)$ is inserted to the right. The lithostratigraphy is denoted by the abbrevations SP - silty peat, HP - humified dark peat, LP - light peat, $G$ - gyttja, Si - silt, and Sa-sand.

Table 3. Description of the pollen zones.

\begin{tabular}{|c|c|c|c|c|}
\hline$P A Z$ & Name & $\begin{array}{c}\text { Age } \\
\text { (cal. ka BP) }\end{array}$ & Pollen zone characteristics and interpretations & $\begin{array}{c}\text { Diagnostic taxa not included in the } \\
\text { pollen diagram (Fig. } 8 \text { ) }\end{array}$ \\
\hline $\mathrm{H} 4$ & $\begin{array}{l}\text { Pinus-Alnus- } \\
\text { Equisetum- } \\
\text { Polypodiaceae }\end{array}$ & $9.3-9.6$ & $\begin{array}{l}\text { The rise and distinct representation of Alnus (most probably } \\
\text { A.glutinosa) and Filipendula show the development of fertile moist } \\
\text { soils. High values of ferns and Equisetum show wet soils, locally. }\end{array}$ & $\begin{array}{l}\text { Asteraceae sect. Cichorium, } \\
\text { Arenaria-type, Picea abies, Tilia } \\
\text { cordata, Selaginella selaginoides }\end{array}$ \\
\hline H3 & $\begin{array}{l}\text { Pinus- } \\
\text { Cyperaceae- } \\
\text { Poaceae }\end{array}$ & $9.6-10.0$ & $\begin{array}{l}\text { Increases in grasses and sedges and decreasing trees show the } \\
\text { opening of local forests. Aspen disappeared. Typha and Solanum } \\
\text { indicate July means of ca } 14^{\circ} \mathrm{C} \text { in late H3. Fluctuating ferns show } \\
\text { variations in soil moisture. }\end{array}$ & $\begin{array}{l}\text { Calluna vulgaris, Circium-type, } \\
\text { Cornus suecica, Cystopteris fragilis, } \\
\text { Sedum, Solanum cf. dulcamara, } \\
\text { Typha latifolia }\end{array}$ \\
\hline $\mathrm{H} 2$ & $\begin{array}{l}\text { Pinus-Betula- } \\
\text { Populus }\end{array}$ & $10.0-10.2$ & $\begin{array}{l}\text { Total pollen influx rapidly rise to } 5000 \text { grains } \mathrm{cm}^{-2} \mathrm{a}^{-1} \text { reflecting local } \\
\text { forests of pine }(50 \% \Sigma \mathrm{P}) \text {, birch }(20-50 \% \Sigma \mathrm{P}) \text {, and Populus }(10 \% \Sigma \mathrm{P}) \text {. } \\
\text { Hippophaë disappeared and Salix show a transitional moister phase } \\
\text { from paz H1. The algae Pediastrum is present in early H2. }\end{array}$ & $\begin{array}{l}\text { Arctostaphyllos uva-ursi, } \\
\text { Nymphaea, Rosaceae, Rubus sp. }\end{array}$ \\
\hline H1 & $\begin{array}{l}\text { Hippophaë- } \\
\text { Artemisia- } \\
\text { Poaceae }\end{array}$ & $\begin{array}{l}\text { Hiatus } \\
\text { Ca. } 10.4-10.5\end{array}$ & $\begin{array}{l}\text { Hippophaё }(70 \% \Sigma \mathrm{P}) \text { dominates. Otherwise, pioneers including } \\
\text { steppe-plants and arctic-alpines, show open vegetation on minerals } \\
\text { soils. Aquatic plants are well represented showing fertile and lime- } \\
\text { rich environments }\end{array}$ & $\begin{array}{l}\text { Achillea-type, Artemisia norvegica- } \\
\text { type, Asteraceae sect. Aster, } \\
\text { Asteraceae sect. Cichorium, } \\
\text { Botrychium, Huperzia selago, } \\
\text { Parnassia palustris Ranunculus } \\
\text { glacialis-type; Sedum }\end{array}$ \\
\hline
\end{tabular}

The macrofossil assemblage in the sand layer $(4-6.5 \mathrm{~cm}$; 10,410 cal years BP) indicates that Hippophaë became abundant on the lake shore, where it was joined by willow shrubs (Salix myrsinites-type). The productivity of the vegetation increased, probably facilitated by the fixation of atmospheric nitrogen by bacteria in the root nodules of Hippophaë (Bond \& Gardner, 1957). The mossy fen community expanded and Phragmites australis became established at the edge of the lake. Chara increased in the lake, together with Potamogeton natans, and the invertebrate community became dominated by the cladoceran Simocephalus, which prefers to live amongst aquatic vegetation.
In the upper silt layer $(6.5-7.5 \mathrm{~cm} ; 10,450$ cal years BP), Hippophae became dominant around the lake as shown by leaves, stellate hairs, budscales and seeds (Fig. 10). Salix spp. played a lesser role. A leaf of S. herbacea, a mountain willow, may have been washed in from higher altitudes in the catchment. Betula pubescens and Populus tremula immigrated and became established near the lake. This date for the B. pubescens immigration is about 400 years later than at Kråkenes on the west coast of southern Norway at a similar latitude $\left(62^{\circ} \mathrm{N}\right)$ and is similar to the date of $B$. pubescens immigration to the Vesterålen Islands $\left(69^{\circ} \mathrm{N}\right)$ in northern Norway (Birks, $2015)$ and the Dovre mountains (62 N; Paus, 2010). As 

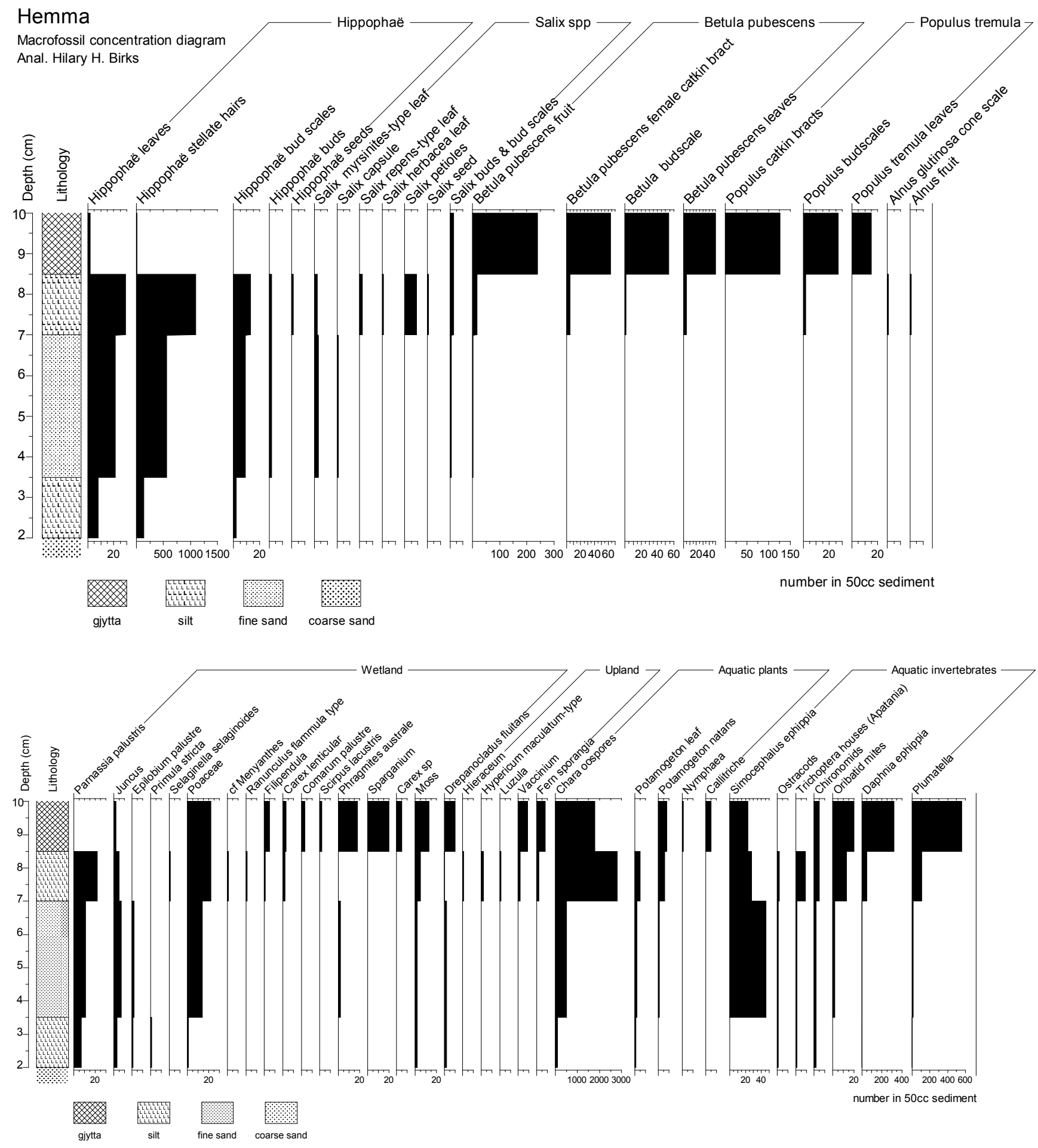

Figure 10. Plant macrofossil concentration diagram from the lacustrine sediments at the base of Hemma core 46. 
H. rhamnoides requires mean July temperatures of at least $11^{\circ} \mathrm{C}$ for vegetative growth (Kolstrup, 1979) and summer temperatures of $14-17^{\circ} \mathrm{C}$ for fruiting (Wikipedia, 2017), summer temperatures were already adequate for the establishment of $B$. pubescens and P. tremula at Hemma. $B$. pubescens requires a $9-10^{\circ} \mathrm{C}$ mean July temperature for growth in continental climates (Odland, 1996). Populus tremula has similar minimum temperature requirements and occurs throughout the boreal forest where it is light-demanding and drought tolerant, but prefers nutrient-rich damp soils (Nikolov \& Helmisaari, 1992) such as would be developed under Hippophä̈.

The lag in birch establishment at Hemma may be due to drought in the relatively continental climate of the Early Holocene and the sharp drainage of the immature sandy soils (Kullman, 1986; Atkinson, 1992), whereas Hippophaë tolerates drought well (Pearson \& Rogers, 1962). Although B. pubescens can tolerate severe mean January temperatures (Nikolov \& Helmisaari, 1992), male catkins are damaged in cold springs leading to poor seed-set (Atkinson, 1992; Beck et al., 2015). Its establishment and spread were possibly hindered by the presence of the melting ice-sheet and associated strong, cold, adiabatic winds. In addition, $B$. pubescens requires mycorrhiza for seedling establishment (Atkinson, 1992), which were probably lacking in the infertile minerogenic substrate exposed by deglaciation. These factors may account for its relatively slow spread across southern Norway in spite of sufficiently high summer temperatures. The remains of Alnus glutinosa in the upper silt could have been introduced by contamination from above, where Alnus is abundant in $\mathrm{H} 4$, as it is very unlikely that Alnus was present locally at 10,440 cal yr BP. Parnassia palustris became abundant in the shoreline vegetation where it was joined by Selaginella selaginoides, cf. Menyanthes, increased Poaceae, Carex spp., and the more thermophilous species, Filipendula ulmaria and Ranunculus flammula-type. Drier ground supported Hieraceum, Hypericum maculatum-type, Luzula and Vaccinium. The terrestrial assemblage probably has no analogues at the present day, as Hippophä̈-dominated lake shores are unknown in Norway. The lake itself probably became shallower, as Chara became very abundant and Potamogeton natans increased. The aquatic invertebrates increased in abundance and diversity.

During the comparable Hippophaë-pollen phase in Våletjern (Hafsten, 1956, 1975), several pollen tetrads of the emergent aquatic Typha latifolia were found, indicating July mean temperatures of at least $14{ }^{\circ} \mathrm{C}$ (Kolstrup, 1979). For comparison, the mean summer temperature at the meteorological station Kise at Lake Mjøsa in Ringsaker, $128 \mathrm{~m}$ a.s.l. and $28 \mathrm{~km}$ south of Hemma is $10.2^{\circ} \mathrm{C}$ and the July 2017 mean temperature was unusually high at $15.5^{\circ} \mathrm{C}$ (DNMI, 2017).

In the dense humified lake gyttja above the minerogenic member (7.5-9 cm; 10,225 cal years BP), the macrofossil assemblage shows an abrupt change, reinforcing the suggestion that there was a short hiatus as a result of sediment sliding. Hippophaë and Salix were replaced by large increases in Betula pubescens and Populus tremula. Hippophaё is light-demanding and intolerant of shade from trees (Pearson \& Rogers, 1962). In the shoreline fen, Parnassia disappeared and was replaced by tall plants characteristic of sedge swamps, such as Filipendula, Comarum palustre, Scirpus lacustris, Phragmites australis, Sparganium and Carex spp. with Drepanocladus fluitans in the ground layer. In the lake, Chara and Potamogeton natans remained abundant and were joined by other macrophytes, Nymphaea alba and Callitriche, which may suggest shallower water. Within the invertebrate assemblage, Daphnia and Plumatella became abundant. The increased organic content (Fig. 6) and reduction of silt deposition implies that the shallow lake was cut off from strong inflows, perhaps becoming isolated from Lake Næra as its level was falling. It became a productive pond with a fringing sedge-fen and surrounded by birch and aspen woodland. The macrofossil information ceases above this point, but subsequent peat formation suggests that the fen plants overgrew the water and their remains filled the former lake. There may be another short hiatus at the transition to peat at $10 \mathrm{~cm}$ (Fig. 6), as the boundary is very sharp, which would not be expected in a normal hydrosere.

In paz H2, the developing soils enabled birch, Pinus and Populus to form forests locally, at c. 10,200 cal yr BP. In Dovre to the northwest, pine increases at a similar time (Paus, 2010). High Populus and Pinus pollen percentages suggest large areas of well-drained soils. During H2, aquatics disappeared, and peat developed over the limnic deposits. At the boundary to paz H3, Pinus and Populus pollen percentages drastically declined. The subsequent expansion of grasses and sedges could suggest opening of the forest, possibly in response to a short cooling episode during the Erdalen events (9700-10,000 cal years BP; Nesje et al., 2001; Paus, 2010; Thoen, 2016). Alternatively, the pollen changes could be local from the peat-forming vegetation. The uppermost paz $\mathrm{H} 4$ shows the local establishment of Alnus c. 9600 cal years BP, probably reflecting the development of an A. glutinosa swamp. The increase in Filipendula may reflect a nitrophilous environment produced by nitrogen fixation in alder roots. Gymnocarpium dryopteris, other ferns and Equisetum could all grow in a wet alder swamp.

\section{The Saug site}

The pollen data are divided into two local pollen assemblage zones, S-1 and S-2 (Fig. 11). The lower gyttja member contained leaves and rootlets of Phragmites and represents a small shallow tarn with reeds. The occurrence of Hippophaë indicates that soils around the dead-ice depression were well drained and immature. Some other pioneer herbs and shrubs such as Artemisia and Salix were also present in the lower pollen spectra. The tarn developed quickly into a wooded swamp, 


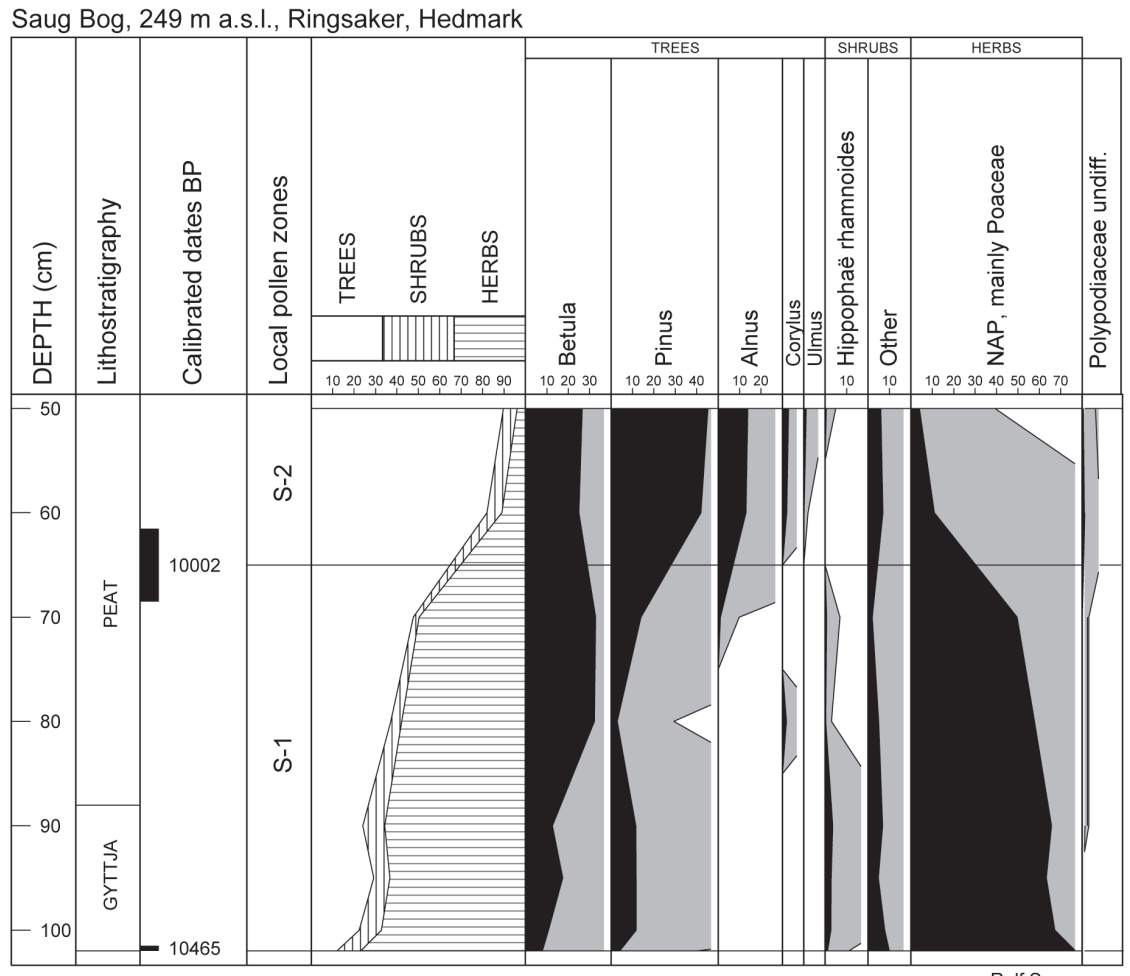

Figure 11. Percentage pollen diagram from Saug. Shaded curves represent 10x exaggeration of the scale. Depths are measured below the bog surface. $N A P=$ non-arboreal pollen.

dominated locally by Poaceae and Betula. Minor amounts of Corylus-pollen occur in the middle of the zone, concurrent with an increase in Pinus pollen, similar to the pattern farther south in the Oslofjorden region (Høeg, H.I, Henningsmoen, K.E., \& Sørensen, R., unpublished manuscript). Pollen zone $\mathrm{S}-1$ can be termed a Betula-Hippophaë-Poaceae assemblage zone. The average rate of deposition was approximately $0.8 \mathrm{~mm} \mathrm{yr}^{-2}$. The appearance of Alnus pollen defines the lower boundary of paz $\mathrm{S}^{-2}$. A mixed pine-birch forest grew on dry soils and an alder swamp forest with ferns occupied the dead-ice depression. In the upper part of zone $\mathrm{S}^{-2}$, small amounts of Ulmus pollen are recorded.

\section{Landslide event}

The boundary between the peat and the overlying diamicton at Hemma is irregular and undulating (Figs. 4 \& 5) and the peat thins out and disappears towards the west, leaving the upper diamicton resting directly on the lower diamicton (the regional till). The upper diamicton appears to be texturally similar to the lower, with clasts of various sizes dispersed in a fine-grained matrix. The boulder bed, resting on the upper diamicton, has an open-work texture with fine-grained matrix preserved only in local pockets (Figs. $4 \& 5$ ). The ab-planes of the boulders are imbricated with the dip to the NE-NNE, thus indicating a flow direction component towards the SW or SSW. Dimensions of boulders tend to increase upwards within the boulder bed (Fig. 5).
The upper diamicton and boulder bed cover the Holocene peat and the only possible interpretation for their formation is a landslide postdating peat formation. However, the gentle slope poses a major problem; even in the failure area it is only about $4^{\circ}$, and in the run-out and depositional area it is about $2.6^{\circ}$. Very few debris-flow deposits are described on such low angles (Rickenmann, 2005). To our knowledge landslides of till material on such gentle slopes have not been described in Norway before. We contacted several geologists working with landslides and none had seen slides or debris flows on such low-angle slopes. Slopes in till are in fact considered to be stable at angles up to $25^{\circ}$ in practical hazard-risk mapping in Norway (Schanke, 2014). We emphasise that the slide occurred at least 4000 years after the area became ice-free when a dense pine forest had become established (Fig. 9). We therefore rule out the possibility that the slide was related to unstable soil conditions after deglaciation.

Our interpretation is that the upper diamicton and boulder bed were deposited as a debris flow derived from the regional till located about $1 \mathrm{~km}$ above the site (Fig. 2). The boulder bed developed into a cohesionless debris flow when water was expelled from the initial water-saturated till landslide. Imbrication and increasing boulder size upwards are typical features of debris flows developed from landslides (Iverson, 1997) and of frontal parts of debris flows formed on steep mountain slopes (Rapp \& Nyberg, 1981). 
We have identified several landslide scars along the southern flank of a large glacial fluting, north of the farm Hemma, on LiDAR images (Fig. 2), which shows the origin of the slide. The width of the scars is some $800 \mathrm{~m}$ and the run-out about one $\mathrm{km}$. We made 10 profiles across the scars, measuring heights relative to undisturbed margins, estimated the volume for each segment and obtained a total volume of about $1 \mathrm{mill}^{3}$. A critical point for landslides on such gentle slopes is the primary failure. We postulate that the till must have been water-saturated at the time of initiation of the slide. However, even more important, there must have been a triggering mechanism for the landslide. The only feasible triggering mechanism is a strong earthquake where shaking led to liquefaction of the till.

Our interpretation of an earthquake-triggered debris flow is supported by studies in Sweden and Finland where several landslides in till on gentle slopes have been mapped near major early-postglacial fault scarps. The faults are considered to result from glaci-isostatic uplift and the interpretation is that slides were triggered by strong earthquakes related to the faulting (Lagerbäck \& Sundh, 2008; Smith et al., 2014; Berglund \& Dahlström, 2015; Mikko et al., 2015; Palmu et al., 2015). Ola Fredin (at the Geological Survey of Norway) has mapped a number of slide scars on gentle slopes in eastern Norway using high-resolution LiDAR data, including the one we describe (Ola Fredin, pers. comm., 2017). He and coworker Marie Keiding consider that the slides were triggered by earthquakes caused by the postglacial isostatic uplift, referring to the studies in Sweden and Finland. However, so far no fault has been discovered. Candidates for faulting near Hemma could be the major Brumunddal Fault zone, located $15 \mathrm{~km}$ east of the Hemma locality, and a fault about $5 \mathrm{~km}$ west of Hemma (Nordgulen, 2005).

The slides in Sweden and Finland, mentioned above, are dated to the Early Holocene mainly by morphological superimposition and cross-cutting, and by the fact that some are covered by thick peat deposits, but there are a few directly related radiocarbon dates to give an absolute age for the timing of the slides. After this paper was accepted for print, Ojala et al. (2018) describe numerous earthquake-related palaeo-landslides in Finland and present a number of radiocarbon ages. They show that landslides took place in three periods, most in the period 9000 to $11,000 \mathrm{cal}$ years BP, but also some between 5000 and 6000 and between 1000 and 3000 cal years BP.

The radiocarbon ages described here provide a maximum age of $6400 \mathrm{cal}$ years BP for the landslide at Hemma, and pollen results show that the slope had been forested for a long time. Silt and clay from the slide must have been washed into Lake Næra, and if such a silt layer is found by coring the lake-bed sediments the timing of the slide could be precisely constrained. Coring the lake is therefore planned for future research.

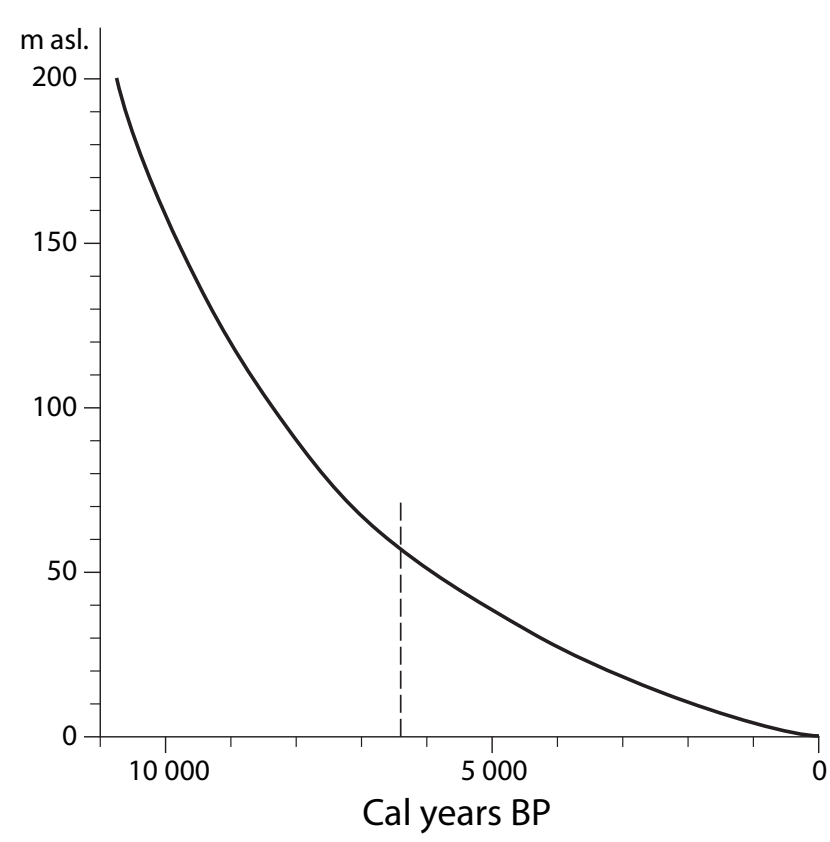

Figure 12. Relative sea-level diagram for Hauerseter. This represents an approximation for the glacio-isostatic uplift also for Hemma, although because global sea level was rising fastest in the Early Holocene, the uplift was initially even faster than shown by the relative sea-level curve. The maximum age for the landslide, which we assume is earthquake triggered, is marked with a dashed line at 6400 cal years BP. By that time three-quarters of the emergence had taken place.

We include a relative sea-level diagram for the Hauerseter ice-front delta that gives the main pattern of isostatic uplift. However, it underestimates the uplift for the period before about 7000 cal years BP, because at that time global sea-level was rising fast. We note that the postulated earthquake took place after at least threequarters of the emergence had taken place (Fig. 12).

\section{Deglaciation}

The radiocarbon ages from Hemma provide in principle only a minimum age of the deglaciation. However, the climate around 10,500 cal years BP was almost as warm as at present (Birks, 2015; Paus \& Haugland, 2017). The pollen and plant macrofossil diagrams show that the lowermost lacustrine sediments contain species that in this regional climate only could exist very close to the retreating ice margin. Thus, we argue that the modelled, calibrated age for the boundary to the underlying till, $10,490 \pm 80$ cal years BP (Fig. 6), represents an accurate age of the deglaciation. This age is considerably more precise than ages that can be obtained for example from exposure dating of erratic boulders, which are frequently used for dating the deglaciation.

The basal radiocarbon sample from Saug yielded 10,446 \pm 200 cal years BP, i.e., with a larger error than the dates from Hemma. However, the ages from the two sites 
overlap at the $68 \%$ significance level. Saug is located about $25 \mathrm{~km}$ south of Hemma and was deglaciated shortly before formation of the ice-margin deposits at Moelv, whereas Hemma was deglaciated later.

Thus, we conclude that the northern part of Mjøsa was deglaciated at around 10,500 cal years BP and we consider this as an approximate age of the ice-margin deposits at Moelv.

We agree with the conclusion of Follestad (2017) that the ice sheet in this area mainly melted down vertically. However, as mentioned in the introduction, we consider that there was nevertheless a retreating ice margin (Sørensen, 1983). The ice-marginal deposits at Minnesund (Fig. 1) consist of more than 70 metres of sand and gravel, the deposition of which must have taken decades. Such a stillstand requires that the ice was still active and that the ice-sheet surface was rising northwards. From Minnesund, the depth of Lake Mjøsa increases to $400 \mathrm{~m}$ (max. depth $453 \mathrm{~m}$ ) over only $16 \mathrm{~km}$, and with the higher relative sea level the depth would have been $600 \mathrm{~m}$ during deglaciation. Along such a reverse slope, calving of the ice margin would have been sustained, promoting rapid retreat, as well as a welldefined ice front.

Accepting the age of $10,600-10,800$ cal years BP for the Minnesund delta, the retreat from Minnesund to Moelv $(70 \mathrm{~km})$ took $100-300$ years, and the retreat rate would be on average $230-700 \mathrm{~m}$ per year. If we consider a longer interval and use 11,200 cal years BP for Aker 2 (Fig. 1), then the retreat rate from there to Moelv ( 110 $\mathrm{km}$ ) was $220 \mathrm{~m}$ per year. These values are of the same order as the Early Holocene retreat in Hardangerfjorden and Sognefjorden (Mangerud et al., 2013).

\section{Conclusions}

- The area around the northern part of Mjøsa was deglaciated 10,500 cal years BP.

- We consider this as an approximate age of the icemarginal deposits at Moelv.

- The ice-margin retreat rate was $230-700 \mathrm{~m}$ per year between Minnesund and Moelv.

- Immature soils, drought, cold spring climate, and cold adiabatic winds from the decaying ice sheet delayed the local forest development, not cold summers.

- Birch formed the first woodland at around $10.2 \mathrm{cal} . \mathrm{ka}$ BP, followed by pine and aspen c. 10.1 ka BP and black alder c. $9.6 \mathrm{ka} \mathrm{BP}$, respectively.
- A debris flow of diamicton (till) was found on a very gentle slope $\left(2.6-4^{\circ}\right)$ and we conclude that it was triggered by an earthquake with a maximum age of 6400 cal years BP.

Acknowledgements. We thank Jan Tore Hemma for informing us about the excavation and for hospitality and help during our visit. We also thank Jo Brendryen who carried out the OxCal age modelling and Eva Bjørseth who made the final versions of most of the illustrations. The two reviewers, Barbara Wohlfarth and Ola Fredin, suggested several improvements.

\section{References}

Aagaard, P. 1976: Mjøsprosjektet. Sedimentologiske undersøkelser 19721974. Norsk institutt for vannforskning, $43 \mathrm{pp}$.

Alexanderson, H. \& Henriksen, M. 2015: A short-lived aeolian event during the Early Holocene in southeastern Norway. Quaternary Geochronology 30, Part B, 175-180. https://doi.org/10.1016/j.quageo.2015.02.014.

Atkinson, M. 1992: Betula pendula Roth (B. verrucosa Ehrh.) and B. pubescens Ehrh. Biological Flora of the British Isles. Journal of Ecology 80, 837-870. https://doi.org/10.2307/2260870.

Beck, P., Caudullo, G., de Rigo, D. \& Tinner, W. 2015: Betula ??? In SanMiguel-Ayanz, J., de Rigo, D., Caudullo, G., Durrant, T. \& Mauri, A. (eds.): European Atlas of Forest Tree Species, Publications Office of the European Union, pp. 70-73.

Berglund, M. \& Dahlström, N. 2015: Post-glacial fault scarps in Jämtland, central Sweden. Geologiska Föreningen $i$ Stockholm Förhandlingar 137, 339-343. https://doi.org/10.1080/11035897.2015.1036361.

Birks, H.H. 2015: South to north: Contrasting late-glacial and earlyHolocene climate changes and vegetation responses between south and north Norway. The Holocene 25, 37-52. https://doi.org/10.1177/0959683614556375.

Birks, H.J.B. \& Peglar, S.M. 2012: Haugtjern. In Birks, H.H., Birks, H.J.B., Bjune, A.E. \& Felde, V. (eds.): Southern and south-eastern Norway. Excursion Guide, Department of Biology, University of Bergen, Bergen, Norway.

Bond, G. \& Gardner, I.C. 1957: Nitrogen fixation in non-legume root nodule plants. Nature 179, 680-681. https://doi.org/10.1038/179680a0.

Bronk Ramsey, C. 2008: Deposition models for chronological records. Quaternary Science Reviews 27, 42-60.

https://doi.org/10.1016/j.quascirev.2007.01.019.

Bronk Ramsey, C. 2009: Bayesian analysis of radiocarbon dates. Radiocarbon 51, 337-360. https://doi.org/10.1017/S0033822200033865.

Bronk Ramsey, C. (2017). Methods for summarizing radiocarbon datasets. Radiocarbon 59, 1809-1833. https://doi.org/10.1017/RDC.2017.108.

DNMI (The Norwegian Meteorological Institute) 2017: eKlima http://sharki.oslo.dnmi.no/portal/page?pageid=73,39035,73_ 39080\&_dad=portal\&_schema=PORTAL.

Follestad, B.A. 2015: Mjøsregionen, kvartærgeologisk kart, scale 1:125,000, Norges geologiske undersøkelse.

Follestad, B.A. 2017: Mjøsområdet formes av istidene. In Dahl, R., Nashoug, O. \& Nystuen, J.P. (eds.): Mjøsområdet - geologi og landskap, Hedmark geologiforening, Hamar, pp. 140-169.

Fægri, K., Iversen, J., Kaland, P. \& Krzywinski, K. 1989: Text book of pollen analyses, 4 . revised edition. Wiley, Chichester, 328 pp. 
Grimm, E.C. 1990: TILIA and TILIA.GRAPH. PC spreadsheet and graphic software for pollen data. INQUA Working Group on DataHandling Methods Newsletter 4, 5-7.

Grimm, E.C. 2004: TGView 2.02. Illinois State Museum, Springfield, Illinois, USA.

Hafsten, U. 1956: Pollen-analytic investigations on the late Quaternary development in the inner Oslofjord area. Universitetet $i$ Bergen Årbok 1956, Naturvitenskapelig Rekke 8, 1-162.

Hafsten, U. 1975: Mjøsområdets natur- og kulturhistorie - slik avsetningene i myrer og tjern beretter. Norsk skogsbruksmuseum Årbok 7, 25-61.

Holtedahl, O. 1953: Norges geologi, Bind II. H. Aschehoug \& Co., Oslo, $1118 \mathrm{pp}$.

Holtedahl, O. 1960: Geology of Norway. Norges geologiske undersøkelse 208, 1-540.

Hughes, A.L.C., Clark, C.D. \& Jordan, C.J. 2010: Subglacial bedforms of the last British Ice Sheet. Journal of Maps 6, 543-563. https://doi.org/10.4113/jom.2010.1111.

Hughes, A.L.C., Gyllencreutz, R., Lohne, Ø.S., Mangerud, J. \& Svendsen, J.I. 2016: The last Eurasian ice sheets - a chronological database and time-slice reconstruction, DATED-1. Boreas 45, 1-45. https://doi.org/10.1111/bor.12142.

Høeg, H.I. 1982: Vegetational development from about 12,000 to 6,000 years B.P. in the counties of Agder and Telemark, South Norway. Norsk Geografisk Tidsskrift 36, 211-224. https://doi.org/10.1080/00291958208552083.

Høgaas, F. \& Longva, O. 2016: Mega deposits and erosive features related to the glacial lake Nedre Glomsjø outburst flood, southeastern Norway. Quaternary Science Reviews 151, 273-291. https://doi.org/10.1016/j.quascirev.2016.09.015.

Iverson, R. 1997: The physics of debris flows. Reviews of Geophysics 35, 245-296. https://doi.org/10.1029/97RG00426.

Kolstrup, E. 1979: Herbs as July temperature indicators for parts of the Pleniglacial and Lateglacial in the Netherlands. Geologie en Mijnbouw 58, 377-380.

Kullman, L. 1986: Demography of Betula pubescens ssp. tortuosa in contrasting habitats close to the birch tree-limit in Central Sweden. Vegetatio 65, 13-20. https://doi.org/10.1007/BF00032122.

Lagerbäck, R. \& Sundh, M. 2008: Early Holocene faulting and paleoseismicity in northern Sweden. Sveriges Geologiska Undersökning Research Paper C 836, 1-80.

Longva, O. 1994: Flood deposits and erosional features from the catastrophic drainage of Preboreal glacial lake Nedre Glåmsjø, SE Norway. PhD thesis, University of Bergen.

Longva, O. \& Thoresen, M. 1989: The age of the Hauerseter delta. Norsk Geologisk Tidsskrift 69, 131-134.

Mangerud, J., Goehring, B.M., Lohne, Ø., Svendsen, J.I. \& Gyllencreutz, R. 2013: Collapse of marine-based outlet glaciers from the Scandinavian Ice Sheet. Quaternary Science Reviews 67, 8-16. https://doi.org/10.1016/j.quascirev.2013.01.024.

Mangerud, J., Halvorsen, L.S., Nashoug, O., Nystuen, J.P., Paus, A. \& Svendsen, J.I. 2017: Sjeldent funn av begravd torv ved Hemma i Ringsaker. In Dahl, R., Nashoug, O. \& Nystuen, J.P. (eds.): Mjøsområdet - geologi og landskap, Hedmark geologiforening, Hamar, pp. 142-143.

Mikko, H., Smith, C.A., Lund, B., Ask, M.V.S. \& Munier, R. 2015: LiDARderived inventory of post-glacial fault scarps in Sweden. Geologiska Föreningen i Stockholm Förhandlingar 137, 334-338. https://doi.org/10.1080/11035897.2015.1036360.

Natvig, Ø. \& Kaland, P.E. 1994: CORE 2.0. Unpublished computer program for stratigraphical data. University of Bergen, Norway.

Nesje, A., Matthews, J.A., Dahl, S.O., Berrisford, M.S. \& Andersson, C. 2001: Holocene glacier fluctuations of Flatebreen and winter precipitation changes in the Jostedalsbreen region, western Norway, based on glaciolacustrine sediment records. Holocene 11, 267-280. https://doi.org/10.1191/095968301669980885.
Nikolov, N. \& Helmisaari, H. 1992: Silvics of the circumpolar boreal forest tree species. In Shugart, H., Leemans, R. \& Bonan, G. (eds.): A Systems Analysis of the Global Boreal Forest, Cambridge University Press, Cambridge, pp. 13-84. https://doi.org/10.1017/CBO9780511565489.003.

Nordgulen, Ø. 2005: Mjøsregionen berggrunnskart, scale 1:250,000. Norges geologiske undersøkelse.

Odland, A. 1996: Differences in the vertical distribution pattern of Betula pubescens in Norway and its ecological significance. Paläoklimaforschung 20, 43-58.

Ojala, A., Markovaara-Koivisto, M., Middleton, M., Ruskeeniemi, T., Mattila, J. \& Sutinen, R. 2018: Dating of paleolandslides in western Finnish Lapland. Earth surface processes and landforms. https://doi.org/10.1002/esp.4408.

Palmu, J.-P., Ojala, A.E.K., Ruskeeniemi, T., Sutinen, R. \& Mattila, J. 2015: LiDAR DEM detection and classification of postglacial faults and seismically-induced landforms in Finland: a paleoseismic database. Geologiska Föreningen i Stockholm Förhandlingar 137, 344-352. https://doi.org/10.1080/11035897.2015.1068370.

Paus, A. 1989: Late Weichselian vegetation, climate, and floral migration at Eigebakken, South Rogaland, southwestern Norway. Review of Palaeobotany and Palynology 61, 177-203. https://doi.org/10.1016/0034-6667(89)90032-8.

Paus, A. 2010: Vegetation and environment of the Rødalen alpine area, Central Norway, with emphasis on the early Holocene. Vegetation History and Archaeobotany 19, 29-51. https://doi.org/10.1007/s00334-009-0228-4.

Paus, A. \& Haugland, V. 2017: Early- to mid-Holocene forest-line and climate dynamics in southern Scandes mountains inferred from contrasting megafossil and pollen data. The Holocene 27, 361-383. https://doi.org/10.1177/0959683616660172.

Pearson, M. \& Rogers, J. 1962: Biological flora of the British Isles, Hippohaë rhamnoides L. Journal of Ecology 50, 501-503. https://doi.org/10.2307/2257460.

Rapp,A. \& Nyberg, R. 1981: Alpine debris flows in northern Scandinavia. Morphology and dating by lichenometry. Geografiska Annaler 63A, 3-4. https://doi.org/10.2307/520831.

Reimer, P.J., Bard, E., Bayliss, A., Beck, J.W., Blackwell, P.G., Bronk Ramsey, C., Buck, C.E., Cheng, H., Edwards, R.L., Friedrich, M., Grootes, P.M., Guilderson, T.P., Haflidason, H., Hajdas, I., Hatté, C., Heaton, T.J., Hoffmann, D.L., Hogg, A.G., Hughen, K.A., Kaiser, K.F., Kromer, B., Manning, S.W., Niu, M., Reimer, R.W., Richards, D.A., Scott, E.M., Southon, J.R., Staff, R.A., Turney, C.S.M. \& van der Plicht, J. 2013: IntCal13 and Marine13 Radiocarbon Age Calibration Curves 0-50,000 Years cal BP. Radiocarbon 55, 1869-1887. https://doi.org/10.2458/azu_js_rc.55.16947.

Rickenmann, D. 2005: Runout prediction methods. In Jakob, M. \& Hungr, O. (eds.): Debris-flow Hazards and Related Problems, Praxis, Springer, Berlin, pp. 306-324. https://doi.org/10.1007/3-540-27129-5_13.

Rye, N. 1979: HAMAR, kvartærgeologisk kart 1916 IV, scale 1:50,000, Norges geologiske undersøkelse.

Schanke, S. 2014: Sikkerhet mot skred i bratt terreng. Norges vassdragsog energidirektorat Veileder 8, 1-45.

Smith, C.A., Sundh, M. \& Mikko, H. 2014: Surficial geology indicates early Holocene faulting and seismicity, central Sweden. International Journal of Earth Sciences 103, 1711-1724. https://doi.org/10.1007/s00531-014-1025-6.

Stuiver, M., Reimer, P. \& Reimer, R. 2017: CALIB 7.1. http://calib.org/calib/ (accessed 01.03.2017).

Sørensen, R. 1982: NORDQUA-Ekskursjonen 1982. PreborealBoreal isavsmelting $i$ Sørøst-Norge. Institutt for Geologi, Norges Landbrukshøgskole, $74 \mathrm{pp}$.

Sørensen, R. 1983: Glacial deposits in the Oslofjord area. In Ehlers, J. (ed.): Glacial deposits in North-west Europe, Balkema, Rotterdam,pp. 19-28. 
Sørensen, R. 1992: The physical environment of Late Weichselian deglaciation of the Oslofjord region, southeastern Norway. Sveriges Geologiska Undersökning Serie Ca 81,339-346.

Thoen, M. 2016: Effekt og omfang av 9.7- og 8.2 kulde-eventene ved Store Finnsjøen på Dovrefjell. MSc thesis, Department of Biology, University of Bergen, $48 \mathrm{pp}$.

Vorren, T. \& Mangerud, J. 2008: Glaciations come and go. In Ramberg, I., Bryhni, I., Nøttvedt, A. \& Rangnes, K. (eds.): The making of a land - Geology of Norway, Norsk Geologisk Forening, Trondheim, pp. 480-533.

Wikipedia: Hippophae rhamnoides. Distribution.

https://en.wikipedia.org/wiki/Hippophae_rhamnoides\#Distribution (accessed 20.05.2018). 